Article

\title{
Factors Influencing High-Rise Gated Community Collective Action Effectiveness: Conceptualization of the Social-Ecological System (SES) Framework
}

\author{
Xuerui Shi (D) and Gabriel Hoh Teck Ling * (D) \\ Faculty of Built Environment and Surveying, University of Technology Malaysia, Skudai 81310, Malaysia; \\ shixuerui@graduate.utm.my \\ * Correspondence: gabriel.ling@utm.my
}

check for updates

Citation: Shi, X.; Ling, G.H.T. Factors Influencing High-Rise Gated Community Collective Action Effectiveness: Conceptualization of the Social-Ecological System (SES) Framework. Buildings 2022, 12, 307. https://doi.org/10.3390/buildings 12030307

Academic Editors: Chyi Lin Lee, Samad Sepasgozar and Lan Ding

Received: 6 January 2022

Accepted: 1 March 2022

Published: 4 March 2022

Publisher's Note: MDPI stays neutral with regard to jurisdictional claims in published maps and institutional affiliations.

Copyright: (C) 2022 by the authors. Licensee MDPI, Basel, Switzerland. This article is an open access article distributed under the terms and conditions of the Creative Commons Attribution (CC BY) license (https:// creativecommons.org/licenses/by/ $4.0 /)$.

\begin{abstract}
Managing common property in gated communities is challenging. Although numerous studies have demonstrated that there are several determinants of collective action effectiveness and performances in gated communities, empirical research drawing on a multidimensional socialecological system (SES) framework in quantitatively exploring relationships between institutionalphysical-social factors and gated community collective action remains lacking. Therefore, based on Ostrom's social-ecological system (SES) framework, this study attempts to identify factors influencing the self-organizing system (collective action) of gated communities in China. Using stratified purposive sampling, ten gated communities with various characteristics in the Taigu district were selected, in which questionnaires were then distributed to 414 households to collect valid data within the communities. Taking the ridge regression as a more robust predictive SES model with a penalty value of $\mathrm{k}=0.1$ and regularization, $\mathrm{R}$ Square of 0.882 , this study, among 14 factors, ultimately identified six key institutional-social-ecological factors based on the descending standardized effect size, and they are: (i) types of community; (ii) presence of leaders; (iii) exclusiveness systems of a gated community; (iv) age of gated community; (v) strict enforcement of rules; and (vi) number of households that affect residents' collective action in terms of community security, hygiene and cleanliness, and facility quality. The research findings provide urban managers and communities novel insights to formulate strategic policies towards sustainable housing and building management.
\end{abstract}

Keywords: institutional-social-ecological factors; gated community; SES framework; collective action effectiveness; ridge regression; Taigu; China

\section{Introduction}

Housing is one of the most pressing topics globally; a plethora of research has been undertaken to address multifaceted housing issues including homeownership affordability [1] and housing sustainability (see Rañeses et al. [2] on climate-adaptive models for future housing). In the housing context of China, scholars, among others, have put particular emphasis on sustainable housing from the triple bottom line angle, which covers environmental impacts (i.e., air quality) on the housing market [3]; housing affordability [4,5]; informal settlements, property rights and poverty [6]; relationships between housing stock and sustainable economic growth [7], impacts of housing demolition on social sustainability [8], and housing security during the COVID-19 pandemic [9]. Despite previous research efforts, improvement of the urban housing environment in Chinese cities still requires more attention in the face of the fast growth of urban development and population as well as the mismatch between Chinese citizens' growing demand and the inadequate provision and suboptimal management of urban services. Overcrowding, overexploitation/congestion, and degradation of urban public resources and services are among the primary issues facing the Chinese housing community, and from the resource (or commons) governance 
perspective, these issues are a form of the tragedy of the (urban) commons (see Hardin [10]; Foster [11]).

As such, the above negative externalities or market failures in terms of the underprovision of public goods contribute to the rapid emergence of enclave urbanism; it is one of the manifestations of the global process, resulting in mosaics of closed, homogeneous spheres that have replaced open, heterogeneous public spaces $[12,13]$. According to $\mathrm{He}$ and Wang [14], the term enclave can be denoted as "an internally homogeneous territorial unit dominated by distinct social, cultural, and economic features, demarcated by a clear boundary, either visible or invisible, to differentiate insiders from outsiders". Gated communities are a typical form of enclave; most studies have shown that gated communities are a worldwide phenomenon and have also become the essential living place for the Chinese population (see Atkinson and Blandy [15]; Glasze et al. [16]; Webster et al. [17]), despite leading to an increasingly fragmented urban mosaic [12] as well as exacerbated residential segregation and social exclusion [18-20]. Moving beyond privatization and centralization for resource governance, Foster [11] believed that the gated community, akin to a common property regime, is a "social governance revolution". As this self-organizing system provides more exclusive goods, it is one of the effective alternatives to addressing the Hardinian commons tragedy because, with the enclosure mechanism, outsiders or non-residents are not allowed to access and use the services and facilities provided in the community, unless permission is granted; hence, this may safeguard and sustain the health of the resources. In other words, to cope with the pressure of urbanization faced by many emerging economies, especially around high demands for urban resources (services), urban managers and housing developers tend to transform those public (shared) resources, typically known as commonpool resources (which are non-exclusionary and subtractable) into club goods (with the attributes of high excludability and low subtractability). By definition, from the typology of economic goods [21], excludability means the obstacle of restricting, whether physically or institutionally, individuals from accessing and using resource units from the resource, while subtractability means that, once an individual has harvested the profit (benefits and enjoyment) of resources, they are not available to other users [22]. However, despite the advantages of a gated community in terms of providing better security and more effective control and management of resource consumption, it appears that the Hardinian tragedy is still not addressed. At times, on top of the overexploitation issue, management problems within gated communities pose a greater concern to the residents [23].

In China's gated communities, due to free riding as well as mismanagement (shirking from the management duty) and underinvestment, leading to the tragedy of the commons, collective action issues are rampant and diverse. Among others, the common issues faced include poor hygiene and cleanliness of public facilities and areas, broken and unmaintained common property (e.g., vandalized lifts, playground, and open spaces), and poor safety and security. For instance, Sun and Webster [24] found that the personal and property safety of some residents living in China's gated communities was threatened by crime. Wang et al. [25] revealed that not all gated communities in China can play their role against social security issues, such as burglary. The homeowner association study of gated communities in Guangzhou by He and Wang [26] found that commons management efficiency within the gated community is low in meeting the demands of residents' daily life. Thus, such collective action complications compromise the residents' satisfaction and quality of life.

Due to the nature of property rights within gated communities, the management of commons in gated communities depends upon the collective action of residents or property owners, and consequently, the failure of commons management in gated communities derives from the residents' collective action dilemmas. Olson [27] argued that an instance of collective action tends to fail because certain individual actors, especially when their number is sizeable, opportunistically overuse resources and cannot resist the temptation of free-riding, and thus fail to pay their fair share for the collective goods. Based on Olson's collective action theory, the failure of facilities management in gated communities 
is realistically a repetition of the tragedy of the commons; therefore, from the perspective of residents, even without outsiders' consumption pressure, ungoverned club goods within a gated community itself caused by ineffective collective action will likely be devolved into common-pool resources (see Webster [28]).

When studying collective action problems, Ostrom proposed the Institutional Analysis and Development framework (IAD framework) [29]; then, based upon the IAD framework and the efforts of scholars, Ostrom [30] placed the problems of institutional management into the social-ecological system and further proposed the SES framework. Contrasted with the IAD framework, rather than placing higher weightage on the institutional processes, the SES framework provides a more detailed and diverse social-ecological variable-oriented and process-oriented analysis [31]. Based on the existing SES literature, not only is the framework commonly applied to the resource management analysis under various socialecological systems, particularly conventional common pool resources relying upon the collective action of assorted actors, such as irrigation systems [32,33], forests [34], fisheries [35], and lakes [36] and some elements in contemporary common resource settings, e.g., neighborhood public open-space governance [37,38], the framework, via a descriptive analysis, has also been innovatively conceptualized in the COVID-19 pandemic setting to better understand which components and factors have played a significant role in tackling the health crisis (see Ling et al. [39]). Through these studies conducted with diverse commons and non-commons settings, the SES framework has proven to be relevantly dynamic, robust, and influential in investigating the key factors in complex social-ecological system operations, and hence, understanding the decision making of the sustainability systems.

As discussed, the effectiveness of collective action in gated communities is influenced by various aspects. Prior empirical studies have encompassed a broad range of factors affecting collective action, such as property rights [40], laws and regulations [41], managerial approaches [42], knowledge sharing [43], residents' types [44], but most of them are limited to single or a few perspectives, which thus have not simultaneously and sufficiently encapsulated the multidimensional institutional-social-ecological components to provide a holistic, integrated understanding of the collective action problems. Although Gao and Ho's work [45] adopted the IAD framework in studying multi-owned housing management in Hong Kong, which has identified development age and scale, group size and agent, and deed of the mutual covenant as factors shaping collective action effectiveness, the total number of factors included in their regressional study, probably due to the limitation of the IAD framework (1st tier) was only 6, which is deemed rather limited. Additionally, despite a recent SES study exploring the collective action components of low-cost housing management in Malaysia (see Wang et al. [23]), which is merely descriptive using explorative factor analysis, to our best knowledge, none of the scholars have studied collective action using the multi-level perspective of SES (which is an expanded and more robust framework compared to IAD), particularly in investigating the inferential relationship of key factors with the collective action effectiveness of gated communities.

Against the background and knowledge gaps above, SES-based collective action empirical research in housing and building management contexts remains a quantitatively unexplored area, especially in the case of the Taigu district, China. As such, this study based in Taigu raises two key research questions, namely, (i) what factors affect Taigu's residents ${ }^{\prime}$ collective action effectiveness and how do they influence their management in the context of a gated community? and (ii) what are the effects of these factors? Taking the SES framework as a theoretical and methodological underpinning, the study of the systematic networks of action situations of gated community residents' collective actions can provide a more informed decision. More specifically, through the conceptualization of SES primary and secondary variables and quantitative ridge regression, this study's objective is to identify key institutional-social-ecological factors affecting gated communities' collective actions in the Taigu district of China.

The study is noteworthy as its contributions are twofold. Not only does it offer practical and policy insights (see more in the conclusion), it also primarily bridges the 
theoretical lacuna of SES framework application in terms of the conceptualization and expansion of SES components and variables within the context of collective action and commons management in gated communities. Specifically, this study contributes to the existing literature on urban commons and collective action using the SES framework; a more nuanced and robust account of the interrelationships between institutional-socialecological factors and gated community collective action performance is established. As such, these contributions from the perspectives of new institutional economics and SES are considerably novel and significant to the disciplines of housing and facilities management. The remainder of the paper is structured into five sections as follows: (i) literature review and conceptual framework; (ii) research methodology; (iii) results and discussion; and finally (iv) conclusions.

\section{Literature Review and Conceptual Framework}

The SES framework originated from Elinor Ostrom's improvement of the Institutional Analysis and Development (IAD framework) in the field of social-ecological systems. The IAD framework was developed by scholars from the Workshop in Political Theory and Policy Analysis at Indiana University led by Vincent Ostrom and Elinor Ostrom over the past few decades. It is a systematic tool for scholars of assorted disciples to communicate with one another, regardless of their broad perspectives, to pave a path toward a higher level of comprehension of a situation [31]. The IAD framework can obtain institutional evaluation and plausible choices through the utilization of resources in context and the participation of actors.

Nevertheless, the IAD framework is controversial because it lacks the diversity and complexity of natural systems and processes [31]. Thereafter, Ostrom further developed the social-ecological system framework (SES framework) upon the shoulders of the IAD framework by expanding the fundamental variables into an increased number of relevant categories [39]. The SES framework inherits the characteristics of the multidisciplinary applicability of the IAD framework and makes up for the flaws in diversity and complexity lacking within the IAD framework in regard to the natural systems and processes [31]. The improved SES framework by McGinnis and Ostrom [46] is shown in Figure 1. The SES framework contains two systems representing the general environment, i.e., social, economic, and political settings (S) and related ecosystems (ECO), and four core subsystems, i.e., resource systems (RS), governance systems (GS), resource units (RU) and actors (A). Meanwhile, the interaction (I) represents the interactive process of these social-ecological systems, and the outcomes $(\mathrm{O})$ represent the results of the systems' interaction.

Furthermore, secondary (second-tier) components of the SES framework, consisting of over 50 variables that may affect the outcomes of social-ecological systems, are shown in Table 1. Through the use of the identified SES attributes, consistent with the application spirit of IAD, we can diagnose and explain the complex and uncertain interactions (activities) and the outcome of a situation [39].

The SES framework includes multilevel concepts that assist in diagnosing problems in complex social-ecological systems. Scholars can study a specific case by utilizing multilevel variables to solve problems and propose solutions [30]. Although the improvement in secondary sub-variables of the SES framework is nearly impeccable, it is not directly applicable to the empirical research at hand. Most commonly, scholars develop an SES framework in line with their research context by reviewing relevant research, such as the SES framework in the context of labor outmigration from Su, et al. [33], and the SES framework for small-scale fisheries from Anderies and Janssen [35]. Consequently, based upon the relevant research, situating the SES framework in the context of commons management in gated communities, we develop a variable-oriented and process-oriented line of argument to analyze the impact of institutional-social-ecological factors on gated community residents' collective action. 


\section{Social, Economic, and PoliticalSettings(S)}

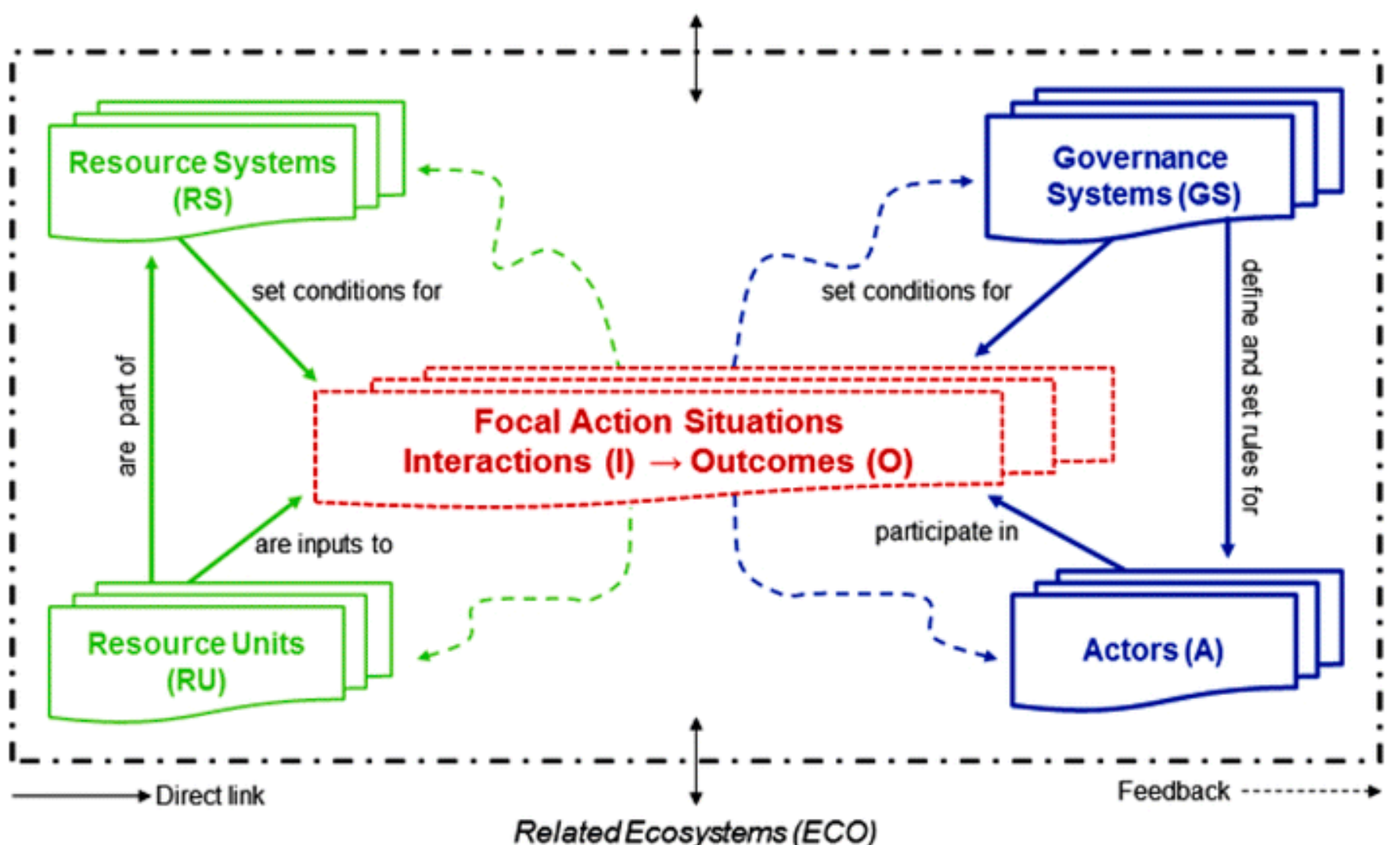

Figure 1. SES framework.

Table 1. Second-level variables of the SES framework.

\begin{tabular}{|c|c|}
\hline First-Tier Variable & Second-Tier Variables \\
\hline \multirow{7}{*}{$\begin{array}{l}\text { Social, economic, and political } \\
\text { settings (S) }\end{array}$} & S1-Economic development \\
\hline & S2_Demographic trends \\
\hline & S3-Political stability \\
\hline & S4-Other governance systems \\
\hline & S5-Markets \\
\hline & S6-Media organizations \\
\hline & S7-Technology \\
\hline \multirow{9}{*}{ Resource systems (RS) } & RS1—Sector (e.g., water, forests, pasture, fish) \\
\hline & RS2-Clarity of system boundaries \\
\hline & RS3-Size of resource system \\
\hline & RS4-Human-constructed facilities \\
\hline & RS5-Productivity of system \\
\hline & RS6-Equilibrium properties \\
\hline & RS7-Predictability of system dynamics \\
\hline & RS8-Stronge characteristics \\
\hline & RS9-Location \\
\hline
\end{tabular}


Table 1. Cont.

\begin{tabular}{|c|c|}
\hline First-Tier Variable & Second-Tier Variables \\
\hline \multirow{9}{*}{ Governance system (GS) } & GS1-Government organizations \\
\hline & GS2-Nongovernment organizations \\
\hline & GS3-Network structure \\
\hline & GS4-Property-rights systems \\
\hline & GS5-Operational-choice rules \\
\hline & GS6-Collective-choice rules \\
\hline & GS7-Constitutional-choice rules \\
\hline & GS8-Monitoring and sanctioning rules \\
\hline & GS9-Location \\
\hline \multirow{7}{*}{ Resource units (RU) } & RU1-Resource unit mobility \\
\hline & RU2-Growth or replacement rate \\
\hline & RU3-Interaction among resource units \\
\hline & RU4-Economic value \\
\hline & RU5-Number of units \\
\hline & RU6-Distinctive characteristics \\
\hline & RU7-Spatial and temporal distribution \\
\hline \multirow{9}{*}{ Actors (A) } & A1-Number of relevant actors \\
\hline & A2-Socioeconomic attributes \\
\hline & A3-History of past experiences \\
\hline & A4-Location \\
\hline & A5-Leadership/entrepreneurship \\
\hline & A6-Norms (trust-reciprocity)/social capital \\
\hline & A7-Knowledge of SES/mental models \\
\hline & A8-Importance of resource (dependence) \\
\hline & A9-Technologies available \\
\hline \multirow{13}{*}{$\begin{array}{l}\text { Action situations: Interactions }(\mathrm{I}) \rightarrow \\
\text { Outcomes }(\mathrm{O})\end{array}$} & I1-Harvesting \\
\hline & I2-Information sharing \\
\hline & I3-Deliberation processes \\
\hline & I4-Conflicts \\
\hline & I5-Investment activities \\
\hline & I6-Lobbying activities \\
\hline & I7-Self-organization activities \\
\hline & I8-Networking activities \\
\hline & 19-Monitoring activities \\
\hline & I10-Evaluative activities \\
\hline & O1-Social performance measures (e.g., efficiency, equity, accountability, sustainability) \\
\hline & O2-Ecological performance measures (e.g., overharvested, resilience, biodiversity, sustainability) \\
\hline & O3-Externalities to other SESs \\
\hline \multirow{3}{*}{ Related ecosystems (ECO) } & ECO1-Climate patterns \\
\hline & ECO2-Pollution patterns \\
\hline & ECO3-Flow into and out of focal SES \\
\hline
\end{tabular}

\subsection{Resource Systems and Units (RSU)}

"Types of gated community" is the variable used to distinguish the social composition and the homogeneity of residents, under the background of housing reform in China. Types 
of gated communities in China can be divided into five categories, namely, new community (mixed community with commodity housing, subsidized housing, and low-rent housing), new community (mixed community with commodity housing and subsidized housing), new community (commodity residential community), post-workplace community (original workplace does not exist), and post-workplace community (workplace exists). Restricted access is one of the characteristics of gated communities, but the segregation of gated communities in China is not strictly reflected in access control; Yip [47] took gated communities in Shanghai as an example, where the "exclusiveness systems of gated communities" are categorized into three types, namely neighborhoods that have no walls or gates, free access neighborhoods with walls and gates, but no access control, and access-controlled neighborhoods. Gao and Ho [45] argued that the "age of gated communities" affects the residents" enthusiasm in participating in collective actions for community management. Residents may be less enthusiastic to participate in collective action within gated communities when the gated community significantly ages. A sizeable number of studies have shown that public service facilities in gated communities have a remarkable impact upon the residents collective action performance [48,49]. In the research, the public service supplement status in gated communities is measured by the "facilities quantity", which is measured by a Likert scale from 1 (Extremely short) to 5 (Ample). Littlewood and Munro [50] found that housing location does affect the residents' collective action, as housing in remote areas is more prone to disrepair and insecurity, and taking the urban central business district (CBD) as the urban center, the study shows the impact of the distance between gated communities and the $\mathrm{CBD}$ on residents' collective action performance.

\subsection{Governance Systems (GS)}

The commons management of gated communities may involve stakeholders with various interests. For instance, Chen and Webster [51] argued that assorted stakeholders have distinct motives for collective action; as such, tenants are more concerned about short-term interests rather than those of the property owners. Following the findings of Chen and Webster [51], the impact of only the owners' or all residents' participation in commons management in regard to collective action performance is considered. Enforcement of rules has a consequential impact on the achievement of collective action in commons management, and Ostrom [21] believed that, once rules become unenforceable, a fatal institutional failure sets in. The strictness of commons management rules is measured by the impunity for violating the rules in the gated communities. Due to the nature of property rights, in the context of a gated community, commons management is governed by a deed of the mutual covenant (DMC), which is a land covenant containing terms that bind all co-owners of a multi-unit or multi-story building held in multiple ownership [52,53]. The DMC is an important premise for ensuring effective collective action by residents, as it is determined by whether a clear commons management covenant in gated communities exists.

\section{3. $\operatorname{Actors}(A)$}

Based upon Olson's collective theory, scholars discovered through empirical studies that the performance of smaller groups in regard to collective action is more effective than that of larger groups $[27,54,55]$. We study the impact of the number of households on collective action and the impact of the group size upon gated community collective action performance. The economic status of residents is highlighted by a sizeable number of scholars, but they hold various views relating to its impact. Yau [44] held that highincome residents demonstrate lower collective action participation, but Osman et al. [56] demonstrated that richer residents have a higher level of willingness to invest in commons management. Meanwhile, Cai and Sheng [57] demonstrated that the presence of leaders in gated communities has a positive effect on residents' collective action, which is embodied in the safeguarding of residents' common rights and interests through their consultation and organizational ability. Residents' willingness to live in gated communities is another noteworthy factor that may determine the performance of collective action [58]. 
Scholars have demonstrated that discontent with the current performance in terms of care and maintenance tends to mobilize participation in commons management $[59,60]$. As a consequence of the above-mentioned information, residential satisfaction is considered within this study. Scholars also demonstrated that expectations of success in collective action have an impact on willingness to participate in collective action [59], which is a factor to be analyzed as well.

\subsection{Outcomes $(\mathrm{O})$}

In this study, the outcomes are the variables reflecting the residents' collective action performance. Residents' collective action performances are represented by three dimensions in the context of a gated community, i.e., community security, hygiene and cleanliness, and facility quality. Community security is regarded as the issue of highest concern by a large number of scholars [15,61-63]. Community security is measured by utilizing a three-point Likert scale as unsafe (1), medium (2), and safe (3). In terms of community hygiene, Chen and Webster [51] regarded cleaning community public areas in a community as collective products of residents' collective actions; it is measured by a three-point Likert scale as dirty (1), medium (2), and clean (3). Several studies found that residents in gated communities associate a significant level of importance with the high-quality facilities provided within the gated communities themselves $[49,64]$. Similarly, to the above-mentioned outcome variables, the facility quality is measured by utilizing a three-point Likert scale as poor (1), medium (2), and good (3). The sum of these three variables was then calculated, and the numerical variable obtained represents the residents' overall collective action performance.

An SES-based conceptual framework is shown in Figure 2, which is the visual expression showcasing interrelationships of second-tier institutional-social-ecological factors with gated communities' collective action performance. Meanwhile, more detailed information on SES variables in terms of means of investigation, measurement level, and assignation scale is shown in Table 2.

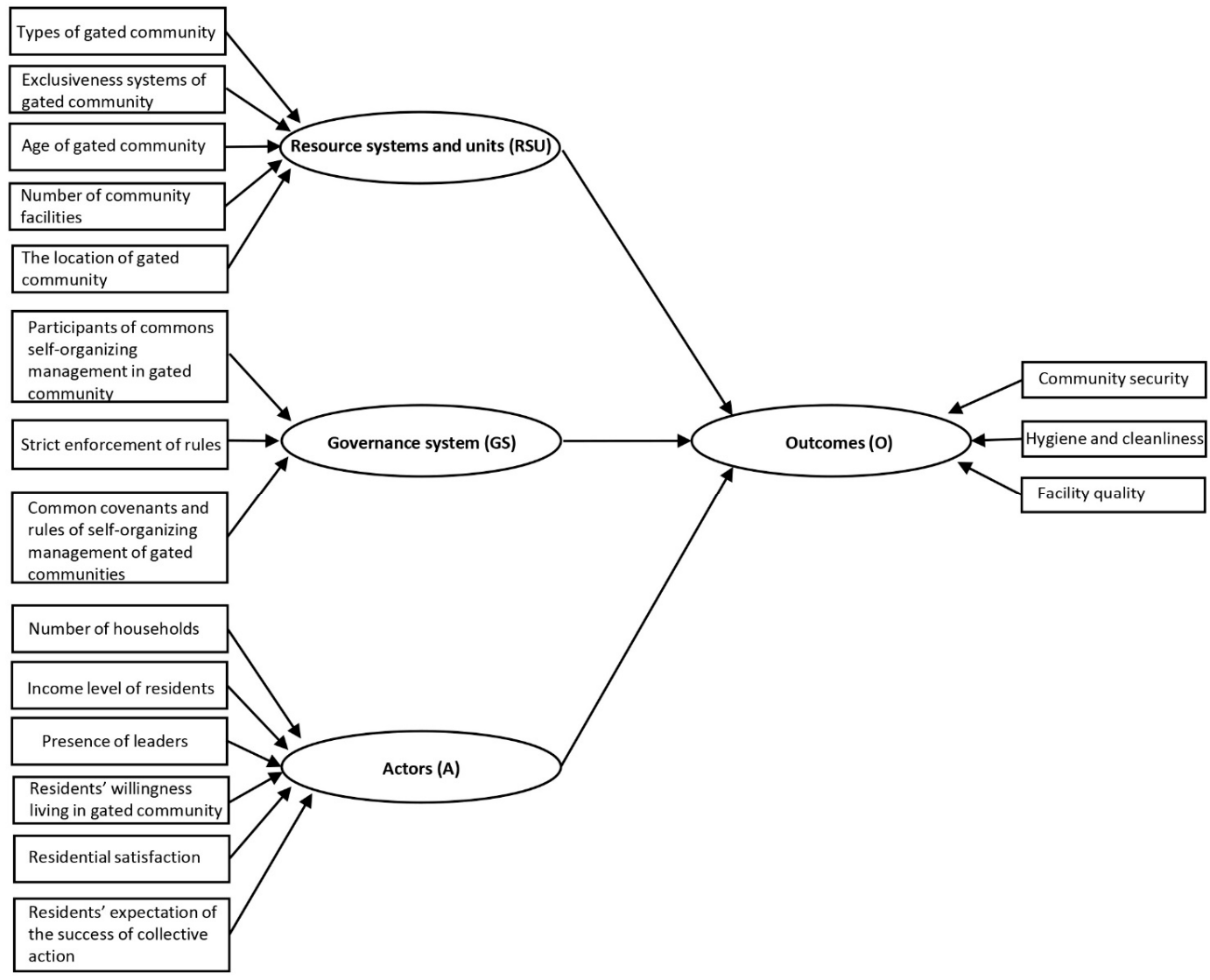

Figure 2. Conceptual framework. 
Table 2. Information of variables researched in this study.

\begin{tabular}{|c|c|c|c|c|}
\hline & Name of Variables & Investigation Ways & $\begin{array}{l}\text { Measurement } \\
\text { Level }\end{array}$ & Variables' Assignment \\
\hline \multirow{3}{*}{ Outcomes $(\mathrm{O})$} & Community security & Questionnaire & $\begin{array}{l}\text { Ordinal level of } \\
\text { measurement }\end{array}$ & Unsafe $=1 ;$ Medium $=2 ;$ Safe $=3$ \\
\hline & Hygiene and cleanliness & Questionnaire & $\begin{array}{l}\text { Ordinal level of } \\
\text { measurement }\end{array}$ & Dirty $=1 ;$ Medium $=2 ;$ Clean $=3$ \\
\hline & Facility quality & Questionnaire & $\begin{array}{l}\text { Ordinal level of } \\
\text { measurement }\end{array}$ & Poor $=1 ;$ Medium $=2 ;$ Good $=3$ \\
\hline \multirow{5}{*}{$\begin{array}{l}\text { Resource } \\
\text { systems and } \\
\text { units (RSU) }\end{array}$} & Types of gated community & Questionnaire & $\begin{array}{l}\text { Nominal level of } \\
\text { measurement }\end{array}$ & $\begin{array}{l}\text { Post-workplace community (original } \\
\text { workplace does not exist) = 1; New } \\
\text { community (mixed community with } \\
\text { commodity housing, subsidized housing } \\
\text { and low-rent housing) = 2; New } \\
\text { community (mixed community with } \\
\text { commodity housing and subsidized } \\
\text { housing) = 3; New community (commodity } \\
\text { housing) }=4 ; \text { Post workplace community } \\
\text { (workplace exists) }=5\end{array}$ \\
\hline & $\begin{array}{l}\text { Exclusiveness systems of } \\
\text { gated community }\end{array}$ & Questionnaire & $\begin{array}{l}\text { Nominal level of } \\
\text { measurement }\end{array}$ & $\begin{array}{c}\text { Neighbors that have no walls / gates }=1 ; \\
\text { Free access neighbors with walls and gates, } \\
\text { but no access control = 2; Access-controlled } \\
\text { neighbors }=3\end{array}$ \\
\hline & Age of gated community & Questionnaire & $\begin{array}{l}\text { Interval-ratio level } \\
\text { of measurement }\end{array}$ & \\
\hline & $\begin{array}{l}\text { Number of community } \\
\text { facilities }\end{array}$ & Questionnaire & $\begin{array}{l}\text { Ordinal level of } \\
\text { measurement }\end{array}$ & $\begin{array}{c}\text { Severe shortage }=1 ; \text { Shortage }=2 ; \text { Passable } \\
=3 ; \text { Enough }=4 ; \text { Ample }=5\end{array}$ \\
\hline & $\begin{array}{l}\text { The location of a gated } \\
\text { community }\end{array}$ & $\begin{array}{l}\text { Documents and records } \\
\text { (based on the geographical } \\
\text { data from Google Maps) }\end{array}$ & $\begin{array}{l}\text { Interval-ratio level } \\
\text { of measurement }\end{array}$ & \\
\hline \multirow{3}{*}{$\begin{array}{l}\text { Governance } \\
\text { system (GS) }\end{array}$} & $\begin{array}{l}\text { Participants of commons } \\
\text { self-organizing } \\
\text { management in a gated } \\
\text { community }\end{array}$ & Questionnaire & $\begin{array}{l}\text { Nominal level of } \\
\text { measurement }\end{array}$ & $\begin{array}{l}\text { All residents participate in commons } \\
\text { management }=1 \text {; Only property owners } \\
\text { participate in commons self-organizing } \\
\text { management of gated community }=2\end{array}$ \\
\hline & Strict enforcement of rules & Questionnaire & $\begin{array}{l}\text { Nominal level of } \\
\text { measurement }\end{array}$ & $\begin{array}{l}\text { Residents violate the rules and were not } \\
\text { punished in gated community }=1 ; \\
\text { Residents violate the rules and were } \\
\text { punished in gated community }=2\end{array}$ \\
\hline & $\begin{array}{l}\text { Common covenants and } \\
\text { rules of self-organizing } \\
\text { management of gated } \\
\text { communities }\end{array}$ & Questionnaire & $\begin{array}{l}\text { Nominal level of } \\
\text { measurement }\end{array}$ & $\begin{array}{l}\text { No clear covenants among residents in } \\
\text { gated community }=1 \text {; Clear covenants } \\
\text { among residents in gated community }=2\end{array}$ \\
\hline \multirow{6}{*}{ Actor (A) } & Number of households & Questionnaire & $\begin{array}{l}\text { Interval-ratio level } \\
\text { of measurement }\end{array}$ & \\
\hline & Income level of residents & Questionnaire & $\begin{array}{l}\text { Interval-ratio level } \\
\text { of measurement }\end{array}$ & \\
\hline & Presence of leaders & Questionnaire & $\begin{array}{l}\text { Nominal level of } \\
\text { measurement }\end{array}$ & $\begin{array}{l}\text { No residents' leaders in gated community } \\
=1 ; \text { Residents' leaders in gated community } \\
\qquad=2\end{array}$ \\
\hline & $\begin{array}{l}\text { Residents' willingness } \\
\text { living in a gated } \\
\text { community }\end{array}$ & Questionnaire & $\begin{array}{l}\text { Ordinal level of } \\
\text { measurement }\end{array}$ & $\begin{array}{l}\text { Want to move out }=1 \text {; No intention to stay } \\
\text { long = } 2 \text {; Uncertain }=3 \text {; No plans to move } \\
\text { out }=4 ; \text { Wish to live permanently }=5\end{array}$ \\
\hline & Residential satisfaction & Questionnaire & $\begin{array}{l}\text { Ordinal level of } \\
\text { measurement }\end{array}$ & $\begin{array}{l}\text { Very dissatisfied }=1 ; \text { Dissatisfied }=2 ; \text { So-so } \\
\quad=3 ; \text { Satisfied }=4 ; \text { Very satisfied }=5\end{array}$ \\
\hline & $\begin{array}{l}\text { Residents' expectation of } \\
\text { the success of collective } \\
\text { action }\end{array}$ & Questionnaire & $\begin{array}{l}\text { Ordinal level of } \\
\text { measurement }\end{array}$ & $\begin{array}{c}\text { Neighbors cannot cooperate }=1 ; \text { Neighbors } \\
\text { may cooperate }=2 ; \text { Neighbors can } \\
\text { cooperate, but not necessarily succeed }=3 ; \\
\text { Neighbors will cooperate and very likely to } \\
\text { succeed }=4 ; \text { Neighbors will cooperate and } \\
\text { succeed }=5\end{array}$ \\
\hline
\end{tabular}


Additionally, to summarize the potential impacts of the variables reviewed above, Table 3 shows the hypothesis of each variable embodied within the conceptual framework.

Table 3. Research Hypotheses.

\begin{tabular}{|c|c|c|}
\hline & Name of Variables & Hypothesis \\
\hline \multirow{5}{*}{$\begin{array}{l}\text { Resource systems } \\
\text { and units (RSU) }\end{array}$} & Types of gated community & $\begin{array}{l}\text { H1: Various types of gated communities bring different } \\
\text { residents' awareness on collective action [65]. }\end{array}$ \\
\hline & $\begin{array}{l}\text { Exclusiveness systems of gated } \\
\text { community }\end{array}$ & $\begin{array}{l}\text { H2: Stricter access control has a positive effect on commons } \\
\text { management in a gated community [66]. }\end{array}$ \\
\hline & Age of gated community & $\begin{array}{l}\text { H3: Older gated communities have a negative effect on } \\
\text { residents' enthusiasm for collective action participation [45]. }\end{array}$ \\
\hline & Number of community facilities & $\begin{array}{l}\text { H4: More facilities supplement in a gated community has a } \\
\text { positive effect on commons management performance [ } 48] \text {. }\end{array}$ \\
\hline & The location of gated community & $\begin{array}{l}\text { H5: The residents' collective action is affected by the location } \\
\text { of real estate }[50,67]\end{array}$ \\
\hline \multirow{3}{*}{$\begin{array}{l}\text { Governance system } \\
\text { (GS) }\end{array}$} & $\begin{array}{l}\text { Participants of commons self-organizing } \\
\text { management in gated community }\end{array}$ & $\begin{array}{l}\text { H6: Fewer commons management participation groups have } \\
\text { a positive impact on collective action performance [42]. }\end{array}$ \\
\hline & Strict enforcement of rules & $\begin{array}{l}\text { H7: Stricter commons management rules are conducive to } \\
\text { collective action performance [21]. }\end{array}$ \\
\hline & $\begin{array}{l}\text { Common covenants and rules of } \\
\text { self-organizing management of gated } \\
\text { communities }\end{array}$ & $\begin{array}{l}\text { H8: Commons management in a gated community are } \\
\text { governed by a deed of the mutual covenant (DMC) [52,53]. }\end{array}$ \\
\hline \multirow{6}{*}{ Actor (A) } & Number of households & $\begin{array}{l}\text { H9: Smaller groups perform better in collective actions } \\
\text { compared to larger groups }[27,54,55] .\end{array}$ \\
\hline & Income level of residents & $\begin{array}{l}\text { H10: High-income residents show lower participation in the } \\
\text { management of commons [44]. } \\
\text { H11: Richer residents are more willing to invest in commons } \\
\text { management [56]. }\end{array}$ \\
\hline & Presence of leaders & $\begin{array}{l}\text { H12: Leaders of the gated community have a positive effect } \\
\text { on residents' collective action [57]. }\end{array}$ \\
\hline & $\begin{array}{l}\text { Residents' willingness living in gated } \\
\text { community }\end{array}$ & $\begin{array}{l}\text { H13: Residents' willingness to live in gated communities has } \\
\text { an impact on collective action. }\end{array}$ \\
\hline & Residential satisfaction & 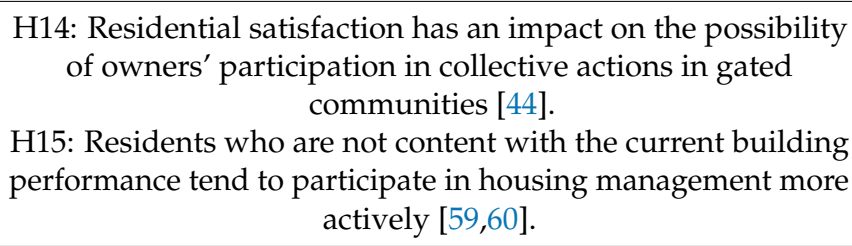 \\
\hline & $\begin{array}{l}\text { Residents' expectation of the success of } \\
\text { collective action }\end{array}$ & $\begin{array}{l}\text { H16: If residents expect their behavior to eventually produce } \\
\text { results, they will be more willing to participate in building } \\
\text { management [59]. }\end{array}$ \\
\hline
\end{tabular}

\section{Research Methodology}

\subsection{Study Area}

As highlighted in the background above, since gated communities in China are also faced with the tragedy of the commons and collective action issues, this SES study was carried out in China. As China experienced a reform of the housing system in 1998, its macroscopic impact should be introduced. Before the 1980s, in regard to concentrating resources on the development of national productive forces, the Chinese government transferred the functioning of social services for citizens to workplaces, which are mostly state-owned; more than $75 \%$ of citizens live in gated communities provided by workplaces. After "China Reform and Opening in 1978", China began to gradually try out a housing 
marketisation reform, and in 1998, the housing marketisation was fully implemented and the lives of citizens were divorced from that of the jurisdiction of the workplaces [68]. Based upon the above social background, the existing gated communities in China can be divided into two categories, namely, "post-workplace community" and "new community". The social composition of the residents in post workplace communities includes the original staff and foreign residents who buy real estate from the original staff and still retain emotional, spatial characteristics. New communities are built after the housing reform which are not influenced by the workplace, and the relationship among residents is a typically geographic relationship [69].

This study selected gated communities in the built-up urban area of the Taigu District within the Shanxi Province as the study area. The location of Taigu is shown in Figure 3. This built-up urban area is about 10.86 square kilometers, and according to the statistics of China's seventh census, the urban population of Taigu was 162,425 . The gated communities in the district reflect the fundamental characteristics of Chinese gated communities similarly to other areas in China, which carried out the housing reform in China as well. According to the data from the "Taigu Housing and Urban Rural Development Bureau", at the end of 2019, there were 300 gated communities in the urban area of Taigu, which included 138 "post-workplace communities" and 162 "new communities".

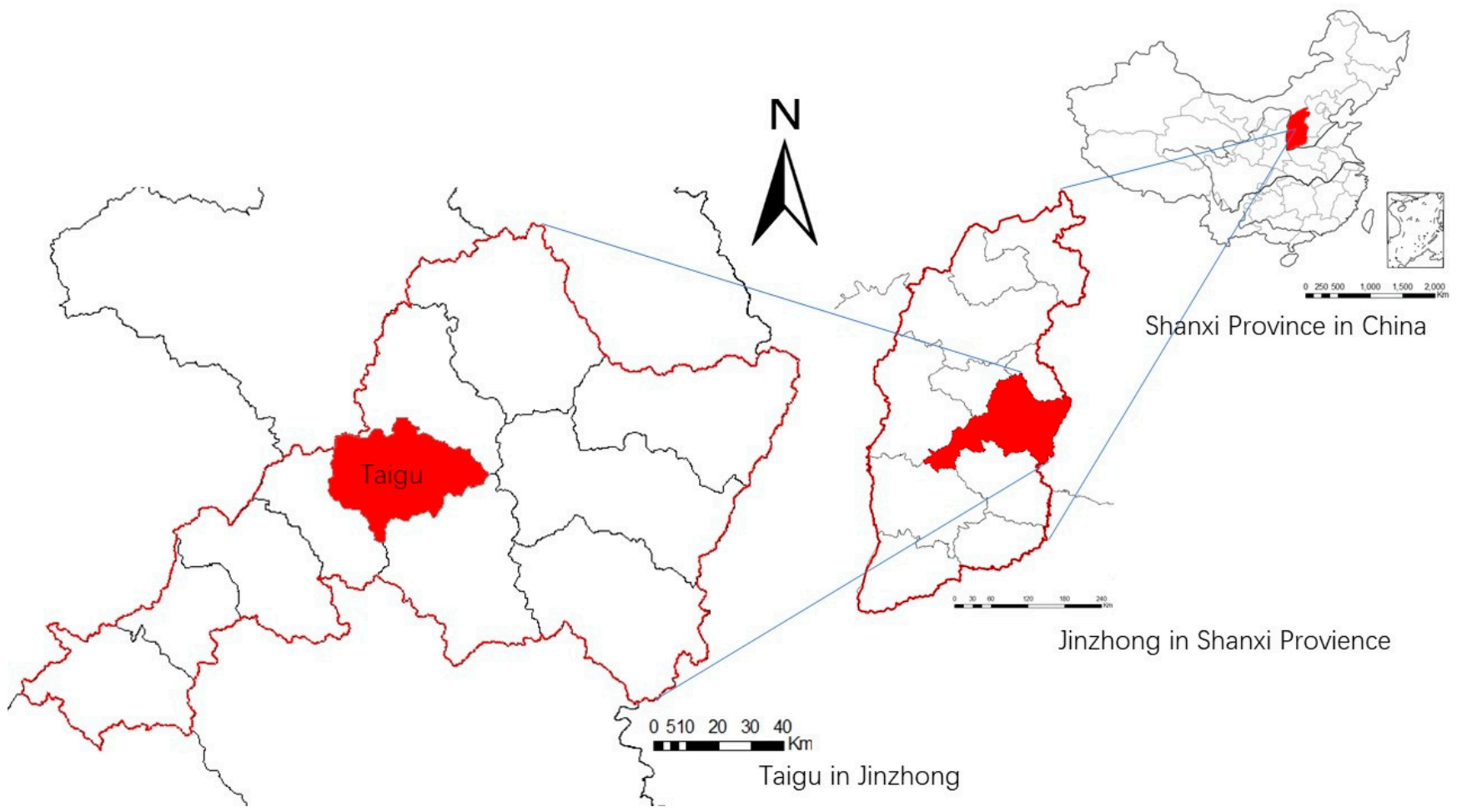

Figure 3. Maps showing the location of the Taigu district.

Within the study area, ten gated communities were selected via stratified, purposive sampling. Considering the types of gated communities as a classification standard, the gated communities in Taigu were divided into two categories and five sub-categories, and using this as a foundation, the gated communities with a resident occupancy ratio less than $60 \%$ and an age of less than six years which have relatively new facilities and an associated community management system that may have not yet fully matured are excluded. Other aspects of gated communities were considered as well, such as location, management mode, size, etc. Building a foundation upon the above conditions through the stratified purposive sampling process, five "post workplace communities" and "new communities" were separately screened out by stratified purposive sampling. The stratified purposive sampling process is shown in Figure 4. 


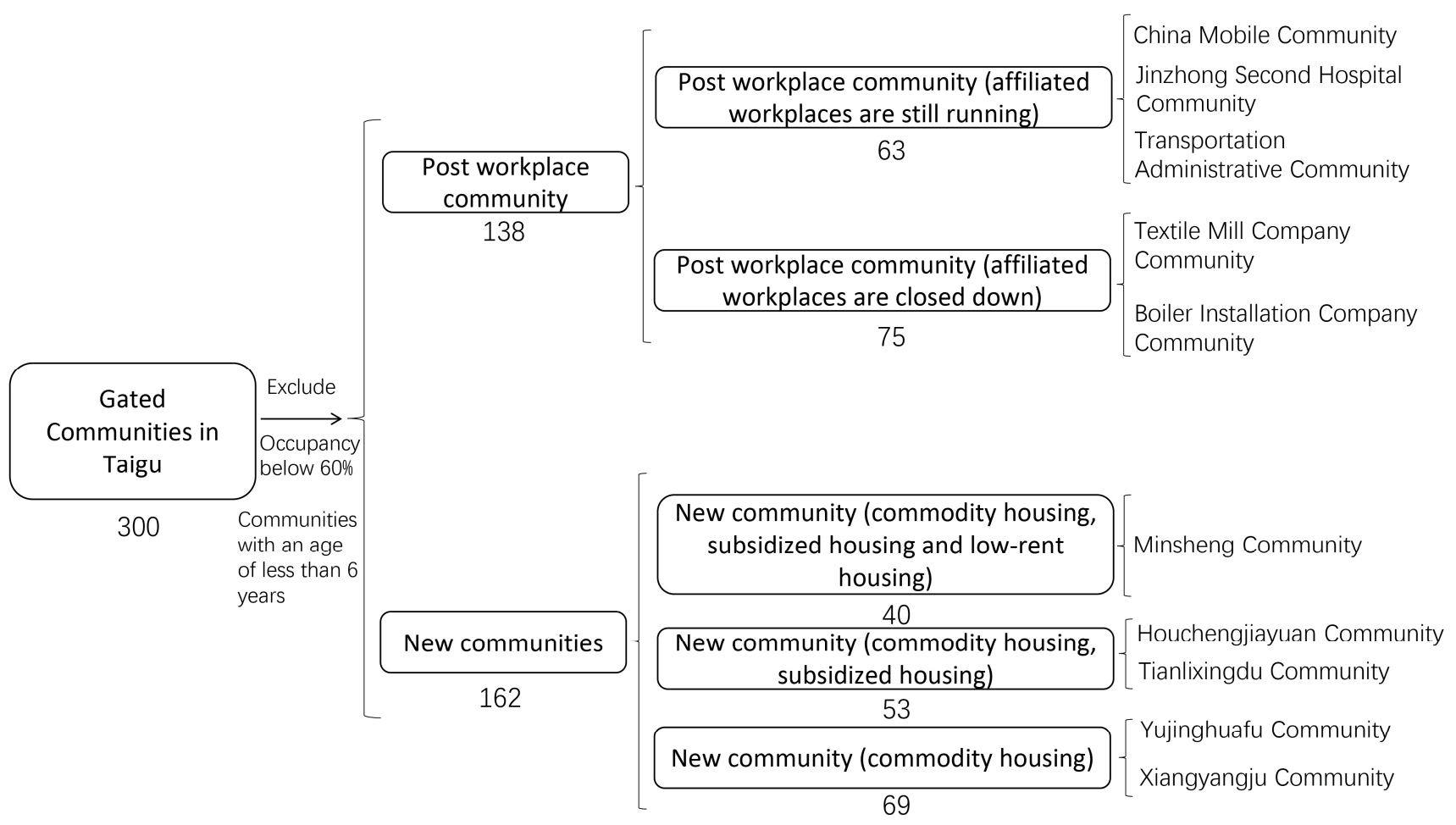

Figure 4. The process of stratified purposive sampling of gated communities.

The age range of these gated communities is 6-27 years old and all the gated communities studied are built as multi-story residential buildings. These communities are within the same social, economic, and political settings (S) and environmental ecosystem (ECO). Location maps and aerial photos of the ten gated communities studied are shown in Figure 5 and Figure 6A-J, respectively.
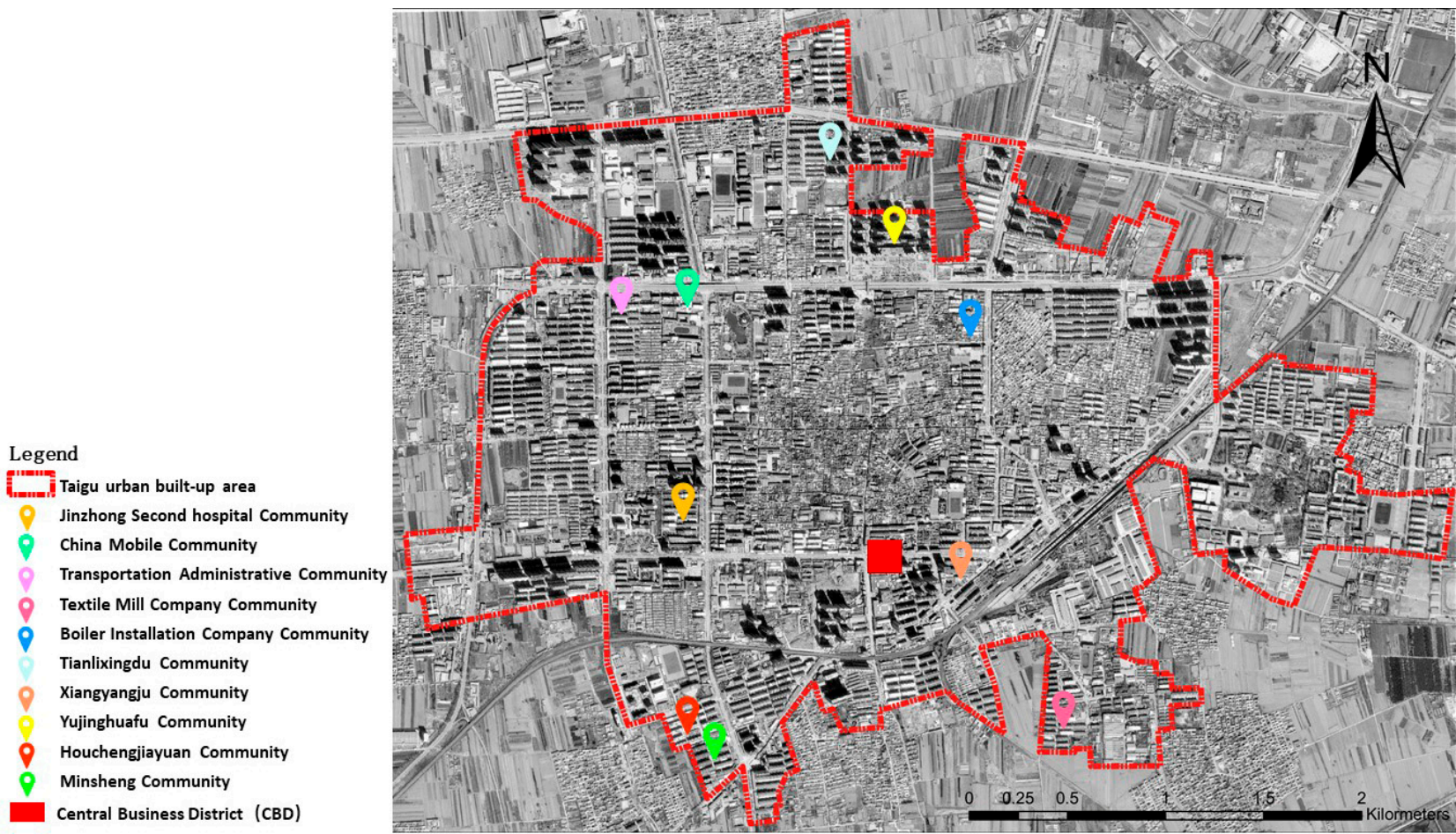

Figure 5. Locations of the ten gated communities in the Taigu urban built-up area. 


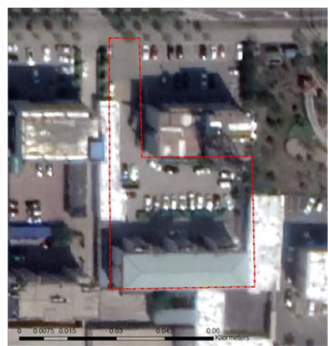

(A)

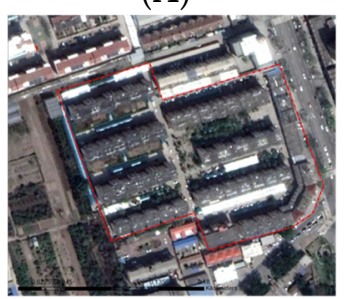

(F)

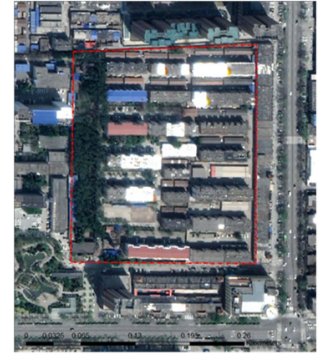

(B)

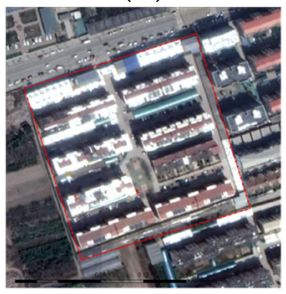

(G)

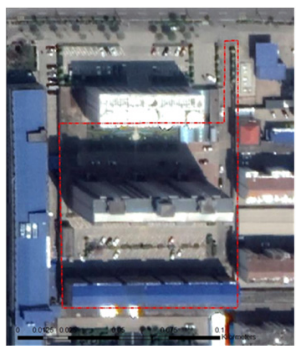

(C)



(H)

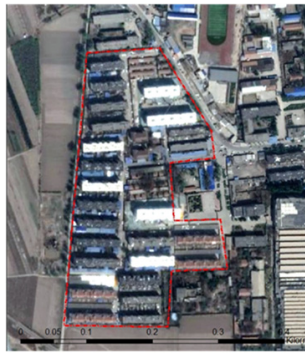

(D)

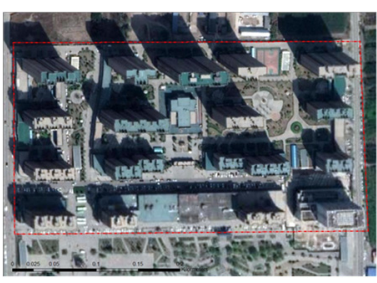

(I)

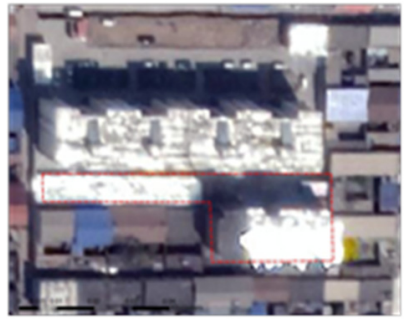

(E)



(J)

Figure 6. Aerial photos of the ten gated communities. (A) China Mobile Community; (B) Jinzhong Second Hospital Community; (C) Transportation Administrative Community; (D) Textile Mill Community; (E) China Mobile Community; (F) Minsheng Community; (G) Houchengjiayuan Community; (H) Tianlixingdu Community; (I) Yujinghuafu Community; (J) Xiangyangju Community.

Meanwhile, information about the spatial and functional structure of the ten gated communities is shown in Table 4 below.

\subsection{Data Collection}

According to the conceptual framework development (see Table 2), the data necessary for the empirical estimation of institutional-social-ecological factors on residents' collective action performance were primarily collected utilizing a structured questionnaire survey among the residents in ten gated communities in Taigu. Based upon the SES framework, the investigated questions are divided into four parts, i.e., What are the residents' collective action performances in gated communities? (Outcomes); What are the attributes of gated communities? (Resource systems and units); What are the management systems that the communities adopt? (Governance system); and What are the attributes of residents in gated communities? (Actors). As the unit of analysis is measured by a household (family), the questionnaire survey was conducted by the household itself. In order to maximize the number of respondents, 50 questionnaires were distributed to residents by purposive sampling in the gated communities which contain more than 50 households. The investigated respondents involved households from each residential building and floor. If the number of households in a gated community was less than 50 households, all residents were surveyed. The purpose of this was to guarantee the comprehensiveness and diversity of the collected data. Based on the above sampling strategy, the number of households involved in the study were 5097 within ten gated communities. According to the data of China's 7th population census (2.62 persons per household), the population size of this study was about 13,355, and from the population, 414 pieces of data were collected. According to Krejcie and Morgan's [70] sample size determination, with a margin of error of $5 \%$ of the sample size and a confidence interval of $95 \%$, the sample size of 414 involved in this study is sufficient and representative. Kindly refer to Apendix A for the contents of the questionnaire. 
Table 4. Spatial structure and function of the ten gated communities.

\begin{tabular}{|c|c|c|c|c|c|c|c|c|c|c|}
\hline & $\begin{array}{l}\text { China Mobile } \\
\text { Community }\end{array}$ & $\begin{array}{l}\text { Jinzhong Second } \\
\text { Hospital } \\
\text { Community }\end{array}$ & $\begin{array}{l}\text { Transportation } \\
\text { Administrative } \\
\text { Community }\end{array}$ & $\begin{array}{c}\text { Textile Mill } \\
\text { Company } \\
\text { Community }\end{array}$ & $\begin{array}{l}\text { Boiler Installation } \\
\text { Company } \\
\text { Community }\end{array}$ & $\begin{array}{l}\text { Minsheng } \\
\text { Community }\end{array}$ & $\begin{array}{l}\text { Houchengijiayuan } \\
\text { Community }\end{array}$ & $\begin{array}{l}\text { Tianlixingdu } \\
\text { Community }\end{array}$ & $\begin{array}{l}\text { Yujinghuafu } \\
\text { Community }\end{array}$ & $\begin{array}{l}\text { Xiangyangju } \\
\text { Community }\end{array}$ \\
\hline Area $\left(m^{2}\right)$ & 2173 & 56,218 & 8300 & 72,371 & 1103 & 35,240 & 28,379 & 72,093 & 95,341 & 2198 \\
\hline Number of households & 15 & 650 & 14 & 942 & 25 & 614 & 284 & 1096 & 1289 & 24 \\
\hline Age of community & 20 & 24 & 20 & 24 & 27 & 12 & 10 & 6 & 6 & 15 \\
\hline $\begin{array}{l}\text { Number of residential } \\
\text { building floors } \\
\text { (According to the Article } \\
3.1 \text { (classification of civil } \\
\text { buildings) of "China civil } \\
\text { building design standard } \\
\text { (GB50352-2019)") }\end{array}$ & $\begin{array}{l}\text { Multi-story } \\
\text { residential housing } \\
\text { with } 4 \text { floors }\end{array}$ & $\begin{array}{l}\text { Multi-story } \\
\text { residential housing } \\
\text { with } 5 \text { floors }\end{array}$ & $\begin{array}{l}\text { High-rise } \\
\text { residential housing } \\
\text { with 14 floors; } \\
\text { Multi-story } \\
\text { residential housing } \\
\text { with } 5 \text { floors }\end{array}$ & $\begin{array}{l}\text { Low-rise residential } \\
\text { housing with } 3 \\
\text { floors; } \\
\text { Multi-story } \\
\text { residential housing } \\
\text { with } 4,5 \text { floors }\end{array}$ & $\begin{array}{l}\text { Low-rise residential } \\
\text { housing with } 3 \\
\text { floors; Multi-story } \\
\text { residential housing } \\
\text { with } 5 \text { floors }\end{array}$ & $\begin{array}{l}\text { Multi-story } \\
\text { residential housing } \\
\text { with } 5 \text { and } 6 \text { floors }\end{array}$ & $\begin{array}{l}\text { Low-rise residential } \\
\text { housing with } 3 \\
\text { floors; Multi-story } \\
\text { residential housing } \\
\text { with } 5 \text { and } 6 \text { floors }\end{array}$ & $\begin{array}{l}\text { Low-rise residential } \\
\text { housing with } 2 \text { floors; } \\
\text { Multi-story residential } \\
\text { housing with } 6 \text { floors; } \\
\text { High-rise residential } \\
\text { housing with } 18\end{array}$ & $\begin{array}{l}\text { High-rise } \\
\text { residential } \\
\text { housing with } \\
16,26,28,30 \\
\text { floors }\end{array}$ & $\begin{array}{l}\text { Multi-story } \\
\text { residential } \\
\text { housing with } 4 \\
\text { floors }\end{array}$ \\
\hline $\begin{array}{l}\text { Types of gated } \\
\text { community }\end{array}$ & $\begin{array}{l}\text { Post-workplace } \\
\text { community } \\
\text { (affiliated } \\
\text { workplaces are still } \\
\text { running) }\end{array}$ & $\begin{array}{l}\text { Post-workplace } \\
\text { community } \\
\text { (affiliated } \\
\text { workplaces are still } \\
\text { running) }\end{array}$ & $\begin{array}{l}\text { Post-workplace } \\
\text { community } \\
\text { (affiliated } \\
\text { workplaces are still } \\
\text { running) }\end{array}$ & $\begin{array}{l}\text { Post-workplace } \\
\text { community } \\
\text { (affiliated } \\
\text { workplaces are } \\
\text { closed down) }\end{array}$ & $\begin{array}{l}\text { Post-workplace } \\
\text { community } \\
\text { (affiliated } \\
\text { workplaces are } \\
\text { closed down) }\end{array}$ & $\begin{array}{l}\text { New community } \\
\text { (commodity } \\
\text { housing, subsidized } \\
\text { housing and } \\
\text { low-rent housing) }\end{array}$ & $\begin{array}{c}\text { New community } \\
\text { (commodity } \\
\text { housing, subsidized } \\
\text { housing) }\end{array}$ & $\begin{array}{l}\text { New community } \\
\text { (commodity housing, } \\
\text { subsidized housing) }\end{array}$ & $\begin{array}{l}\text { New } \\
\text { community } \\
\text { (commodity } \\
\text { housing) }\end{array}$ & $\begin{array}{l}\text { New community } \\
\text { (commodity } \\
\text { housing) }\end{array}$ \\
\hline
\end{tabular}




\subsection{Analysis Method}

To verify the research hypotheses, this paper adopted an inferential analysis, which helped identify what the key institutional-social-ecological variables influencing residents collective action performance are. More specifically, to avoid collinearity issues among the institutional-social-ecological factors, ridge regression was utilized as the predictive SES model for the study. The ridge regression analysis was first proposed by Hoerl in 1962 to deal with the problem of collinearity of independent variables in the analysis; thereafter, Hoerl and Kennard [71] cooperated to further explain ridge regression in 1970. It is a biased estimation method based upon the ordinary least-square estimation which can be seen as an improvement over the ordinary least-square estimation. It abandons the unbiased nature of the ordinary least-square method and reduces accuracy to obtain reliable and practical regression coefficients. In short, it is a robust method when compared to the ordinary least-square estimation in fitting the data with collinearity. An ordinary leastsquare equation is shown in Equation (1), while the ridge regression model is expressed by Equation (2), a slight modification of the ordinary least-square equation.

$$
\begin{gathered}
\theta(\alpha)=\left(X^{T} X\right)^{-1} X^{T} y \\
\theta(\alpha)=\left(X^{T} X+\alpha I\right)^{-1} X^{T} y
\end{gathered}
$$

In these two equations, $X$ represents the number of samples $x$ the characteristic number of samples in the matrix of regressors; $y$ is the sample output vector; $\theta(\alpha)$ is the characteristic number of samples $\times 1$ vector of regression coefficients; $\alpha$ is the value of penalty; I represents the identity matrix; -1 is the inverse matrix; and $T$ is the transpose matrix.

As shown in Equation (1), when $X$ is not the column non-singular matrix, or the linear correlation amongst some columns is relatively large, the determinant of $X^{T} X$ is close to zero; that is, $X^{T} X$ is close to the singularity. At this time, the error in calculating $\left(X^{T} X\right)^{-1}$ will be large, the ordinary least-square method lacks stability and reliability. In order to solve the above issue, we need to transform the unsatisfiability problem into a satisfiability problem by adding a regularization term to the above loss function. Thus, Equation (2) derived from Equation (1) helps address the collinearity issue among independent variables. As shown by Equation (2), with the increase of $\alpha$, the absolute value of $\theta(\alpha)$ tends to be smaller and smaller, and when $\alpha$ goes to infinity, $\theta(\alpha)$ goes to zero, and the $\theta(\alpha)$ trace that changes with the change of $\alpha$ is called ridge trace. In the actual calculation, when the $\theta(\alpha)$ trace tends to be stable, the corresponding $\alpha$ value is the penalty to be taken. A prerequisite worth mentioning is that the least-square estimation requires the dependent variable to be a numerical variable. As a modification of the least square estimation, the dependent variable of the ridge regression model also needs to meet this requirement, and the measurement level of residents' collective action performance in this study accords with this prerequisite.

However, prior to adopting the ridge regression analysis, the multicollinearity among independent variables was computed using both Pearson bivariate correlations and variance inflation factor (VIF) analysis. When the Pearson bivariate correlation coefficient exceeds the threshold value of $0.7-0.8$, this indicates that the correlation between two independent variables is significant. Moreover, when the value of VIF is greater or equal to 10, it suggests that multi-collinearity is significant amongst independent variables. When Pearson bivariate correlations and VIF both show significant collinearity among independent variables, ridge regression can be used as a regression model.

\section{Results and Discussion}

\subsection{Descriptive Statistics}

According to the data collection method, a total of 414 valid pieces of data were collected from ten gated communities in Taigu. Based on the collected data, the collinearity 
among independent variables was tested by the Pearson bivariate correlation matrix and variance inflation factor. As shown in Table 5 (Pearson bivariate correlation matrix) and Table 6 (Variance inflation factor (VIF)), there was significant collinearity among independent variables; therefore, ridge regression was employed for this study.

Table 5. Pearson bivariate correlation matrix.

\begin{tabular}{|c|c|c|c|c|c|c|c|c|c|c|c|c|c|c|}
\hline & RSU1 & RSU2 & RSU3 & RSU4 & RSU5 & GS1 & GS2 & GS3 & A1 & A2 & A3 & A4 & A5 & A6 \\
\hline RSU1 & 1 & & & & & & & & & & & & & \\
\hline RSU2 & $0.767 * *$ & 1 & & & & & & & & & & & & \\
\hline RSU3 & -0.069 & $-0.369 * *$ & 1 & & & & & & & & & & & \\
\hline RSU4 & $0.566^{* *}$ & $0.757^{* *}$ & $-0.457^{* *}$ & 1 & & & & & & & & & & \\
\hline RSU5 & $0.143^{* *}$ & $0.609^{* *}$ & $-0.466^{* *}$ & $0.656^{* *}$ & 1 & & & & & & & & & \\
\hline GS1 & $0.687^{* *}$ & $0.534^{* *}$ & $-0.186^{* *}$ & $0.365^{* *}$ & $0.277^{* *}$ & 1 & & & & & & & & \\
\hline GS2 & $0.648^{* *}$ & $0.569 * *$ & 0.072 & $0.572 * *$ & $0.202^{* *}$ & $0.327^{* *}$ & 1 & & & & & & & \\
\hline GS3 & $0.818^{* *}$ & $0.711^{* *}$ & $0.156^{* *}$ & $0.603^{* *}$ & $0.175^{* *}$ & $0.459 * *$ & $0.804^{* *}$ & 1 & & & & & & \\
\hline A1 & $-0.175^{* *}$ & $0.267^{* *}$ & $-0.455^{* *}$ & $0.198 * *$ & $0.323 * *$ & $-0.219^{* *}$ & 0.078 & 0.039 & 1 & & & & & \\
\hline $\mathrm{A} 2$ & $0.385^{* *}$ & $0.550 * *$ & $-0.751 * *$ & 0.570 ** & $0.451^{* *}$ & $0.432 * *$ & $0.243 * *$ & $0.266^{* *}$ & $0.377^{* *}$ & 1 & & & & \\
\hline $\mathrm{A} 3$ & $0.759 * *$ & $0.907 * *$ & $-0.157^{* *}$ & $0.688^{* *}$ & $0.558^{* *}$ & $0.587^{* *}$ & $0.653 * *$ & $0.783^{* *}$ & $0.308^{* *}$ & $0.430 * *$ & 1 & & & \\
\hline A4 & $0.664^{* *}$ & $0.780 * *$ & -0.293 ** & $0.589 * *$ & $0.414^{* *}$ & $0.338^{* *}$ & $0.500 * *$ & $0.580 * *$ & $0.257^{* *}$ & $0.455^{* *}$ & $0.737^{* *}$ & 1 & & \\
\hline A5 & $0.539 * *$ & $0.531 * *$ & 0.041 & $0.381 * *$ & $0.229^{* *}$ & $0.160 * *$ & $0.548 * *$ & $0.643^{* *}$ & $0.243^{* *}$ & $0.263 * *$ & $0.564 * *$ & $0.586^{* *}$ & 1 & \\
\hline A6 & $0.688^{* *}$ & $0.783 * *$ & $-0.279 * *$ & $0.610^{* *}$ & $0.460 * *$ & $0.432 * *$ & $0.555^{* *}$ & $0.631^{* *}$ & $0.270 * *$ & 0.491 ** & $0.773 * *$ & $0.836^{* *}$ & $0.666^{* *}$ & 1 \\
\hline
\end{tabular}

Notes. RSU1 = Types of a gated community, RSU2 = Exclusiveness systems of a gated community, RSU3 = Age of gated community, RSU4 = Number of community facilities, RSU5 = The location of a gated community, GS1 = Participants of commons self-organizing management in a gated community, GS2 = Strict enforcement of rules, GS3 = Common covenants and rules of self-organizing management of gated communities, A1 = Number of households, A2 = Income level of residents, A3 = Presence of leaders, A4 = Residents' willingness living in a gated community, A5 = Residential satisfaction, A6 = Residents' expectation of the success of collective action. ** Correlation is significant at the 0.01 level (2-tailed).

Table 6. Variance inflation factor (VIF).

\begin{tabular}{cc}
\hline Variables' Name & Variance Inflation Factor (VIF) \\
\hline Types of gated community & 27.157 \\
\hline Exclusiveness systems of gated community & 15.431 \\
\hline Age of gated community & 13.704 \\
\hline Number of community facilities & 6.962 \\
\hline Location of gated community & 8.085 \\
\hline $\begin{array}{c}\text { Participants of commons self-organizing management in a } \\
\text { gated community }\end{array}$ & 5.156 \\
\hline $\begin{array}{c}\text { Strict enforcement of rules } \\
\text { Common covenants and rules of self-organizing } \\
\text { management of gated communities }\end{array}$ & 3.174 \\
\hline Number of households & 14.116 \\
\hline Income level of residents & 11.523 \\
\hline Presence of leaders & 4.045 \\
\hline Residents' willingness to live in gated community & 33.674 \\
\hline Residential satisfaction & 4.414 \\
\hline Residents' expectation of the success of collective action & 3.201 \\
\hline
\end{tabular}


Table 7 shows the descriptive statistics of all the respondents in the survey. The average value of residents' collective action performances within the sample was 7.74 with a standard deviation of 1.494 . The process of data sampling was purposive sampling, and as such, there was no obvious preference for the sample number of various types of gated communities. The average level of the exclusiveness systems of a gated community was 2.28 (within a 3-point scale), which alludes to the prevalence of gated communities with relatively stringent access control. The age of the gated communities was between 6-27 years and the average age of a gated community was 15.54, of which the standard deviation was 7.463. The average score of the number of community facilities was 3.23 , indicating that a majority of respondents accept the supply of public service facilities in gated communities in which they are living. The distance between gated communities and the CBD was 500-2000 m, according to the value of the mean and standard deviation. There were remarkable differences among the gated communities' locations. The average level of participants of commons self-organizing management in gated communities was 1.76, which alluded to the fact that commons management power lies in the property owners in a majority of gated communities. The mean value of the strict enforcement of rules was 1.44 , as the rules of the gated communities surveyed are not strict. In addition, the mean value of common covenants and the rules of self-organizing management in the gated communities was 1.40, as it alluded to a considerable number of gated communities that did not have clear commons management rules. According to the data of the number of households, the largest gated community had 1289 households and the smallest gated community had only 15 households; thus, there was an obvious variation among gated communities. The income gap of respondents was consequential; the low-rent housing was only 2400 yuan per square meter (converted based on China's property rights system) and the most expensive housing price was 8000 yuan per square meter. The average value of the presence of leaders was 1.52 and the number of respondents living in gated communities with leaders was essentially the same as the respondents living in gated communities without leaders. Based on the descriptive statistics of the three variables representing residents' attitudes, the respondents were biased toward a positive attitude.

Table 7. Descriptive statistics of the variables $(n=414)$.

\begin{tabular}{|c|c|c|c|c|}
\hline & Minimum & Maximum & Mean & Std. Deviation \\
\hline Residents' collective action performance & 4 & 9 & 7.74 & 1.494 \\
\hline Types of community & 1 & 5 & 3.25 & 1.441 \\
\hline Exclusiveness systems of gated community & 1 & 3 & 2.28 & 0.826 \\
\hline Age of gated community & 6 & 27 & 15.54 & 7.463 \\
\hline Number of community facilities & 1 & 5 & 3.23 & 1.222 \\
\hline Location of gated community & 500 & 2000 & 1387.68 & 382.825 \\
\hline $\begin{array}{l}\text { Participants of commons self-organizing management in gated } \\
\text { community }\end{array}$ & 1 & 2 & 1.76 & 0.429 \\
\hline Strict enforcement of rules & 1 & 2 & 1.44 & 0.497 \\
\hline $\begin{array}{l}\text { Common covenants and rules of self-organizing management of } \\
\text { gated communities }\end{array}$ & 1 & 2 & 1.40 & 0.490 \\
\hline Number of households & 15 & 1289 & 608.40 & 437.921 \\
\hline Income level of residents & 2400 & 8000 & 5396.38 & 1448.022 \\
\hline Presence of leaders & 1 & 2 & 1.52 & 0.500 \\
\hline Residents' willingness to live in gated community & 1 & 5 & 3.48 & 1.121 \\
\hline Residential satisfaction & 1 & 5 & 3.58 & 0.810 \\
\hline Residents' expectation of the success of collective action & 1 & 5 & 3.58 & 0.960 \\
\hline
\end{tabular}




\subsection{Ridge Regression Analysis}

The institutional-social-ecological factors were utilized as independent variables while the residents' collective action performances were utilized as dependent variables within the ridge regression model for the analysis. Since the variables were distinct in measurement, in order to overcome the problem of bias within the analysis result caused by the measurement of variables, optimal scaling was used to standardize the variables in the ridge regression model. As shown in the ridge trace (Figure 7), when the change in the ridge coefficients of variables tends to be stable and the information loss is minimal, the value of the penalty was 0.1 , which is the parsimonious model of the ridge regression. This means that it was able to explain the data with a minimum number of predictors.



Figure 7. Ridge trace.

It is worth noting that, in order to predict the accuracy of ridge regression with a small sample size in practice, 10 -fold cross-validation was adopted, which is a resampling method. It partitioned the 414 samples into 10 equal-sized subsamples. Of the 10 subsamples, a single subsample was retained as the subsample test of validation data, while the remaining nine subsamples were used as training data. The cross-validation was repeated 10 times, with each of the 10 subsamples being used exactly one time as the subsample test. The training subsamples were analyzed and the tested subsample validated the analysis results of the training set. Finally, the errors of each round of training set and test set results were averaged to obtain an accurate estimation of the error in the model's predictive performance (estimate of expected prediction error). The information of the ridge models in various penalties is shown in ridge models in Table A1, Appendix A.

The ridge regression results of the parsimonious model are shown in Table 8 (ANOVA), Table 9 (Model summary), and Table 10 (Regression coefficients). 
Table 8. ANOVA results.

\begin{tabular}{cccccc}
\hline & Sum of Squares & Df & Mean Square & F & Sig. \\
\hline Regression & 364.945 & 23 & 15.867 & 126.150 & 0.000 \\
\hline Residual & 49.055 & 390 & 0.126 & & \\
\hline Total & 414.000 & 413 & & & \\
\hline
\end{tabular}

Table 9. Model Summary.

\begin{tabular}{|c|c|c|c|c|c|c|c|c|}
\hline & \multirow{2}{*}{ Multiple R } & \multirow{2}{*}{ R Square } & \multirow{2}{*}{$\begin{array}{l}\text { Adjusted } \\
\text { "R Square" }\end{array}$} & \multirow{2}{*}{$\begin{array}{l}\text { Regularization } \\
\text { "R Square" }\end{array}$} & \multirow{2}{*}{$\begin{array}{c}\text { Apparent } \\
\text { Prediction Error }\end{array}$} & \multicolumn{3}{|c|}{ Expected Prediction Error } \\
\hline & & & & & & Estimate $^{a}$ & Std. Error & $\mathbf{n}$ \\
\hline $\begin{array}{c}\text { Standardized Data } \\
\text { Raw Data }\end{array}$ & 0.939 & 0.883 & 0.876 & 0.882 & $\begin{array}{l}0.118 \\
0.264\end{array}$ & $\begin{array}{l}0.133 \\
0.296\end{array}$ & $\begin{array}{l}0.014 \\
0.031\end{array}$ & 414 \\
\hline
\end{tabular}

a Penalty 0.100 .

Table 10. Regression coefficients (Dependent variable: Residents' collective action performances).

\begin{tabular}{|c|c|c|c|c|c|}
\hline & \multicolumn{2}{|c|}{ Standardized Coefficients } & \multirow[b]{2}{*}{$\mathrm{df}$} & \multirow[b]{2}{*}{$\mathbf{F}$} & \multirow[b]{2}{*}{ Sig } \\
\hline & Beta & $\begin{array}{l}\text { Bootstrap (1000) } \\
\text { Estimate of Std. Error }\end{array}$ & & & \\
\hline Types of community & 0.337 & 0.023 & 4 & 216.615 & 0.000 \\
\hline Exclusiveness systems of gated community & 0.305 & 0.015 & 2 & 404.174 & 0.000 \\
\hline Age of gated community & -0.075 & 0.014 & 1 & 27.200 & 0.000 \\
\hline Number of community facilities & 0.045 & 0.037 & 2 & 1.491 & 0.226 \\
\hline Location of gated community & -0.028 & 0.016 & 1 & 2.971 & 0.086 \\
\hline $\begin{array}{l}\text { Participants of commons self-organizing management in } \\
\text { gated community }\end{array}$ & 0.036 & 0.023 & 1 & 2.553 & 0.111 \\
\hline Strict enforcement of rules & 0.054 & 0.021 & 1 & 6.776 & 0.010 \\
\hline $\begin{array}{c}\text { Common covenants and rules of self-organizing } \\
\text { management of gated communities }\end{array}$ & 0.016 & 0.012 & 1 & 1.776 & 0.183 \\
\hline Number of households & 0.035 & 0.016 & 1 & 4.975 & 0.026 \\
\hline Income level of residents & 0.041 & 0.029 & 1 & 2.077 & 0.150 \\
\hline Presence of leaders & 0.323 & 0.022 & 1 & 208.333 & 0.000 \\
\hline Residents' willingness to live in gated community & 0.039 & 0.027 & 3 & 2.004 & 0.113 \\
\hline Residential satisfaction & 0.038 & 0.045 & 2 & 0.718 & 0.489 \\
\hline Residents' expectation of the success of collective action & 0.017 & 0.036 & 2 & 0.217 & 0.805 \\
\hline
\end{tabular}

According to the results of Analysis of Variance (ANOVA), the significance of the ridge regression model was less than 0.05 , which can explain the impact of institutionalsocial-ecological factors on commons management performances. Referring to Table 9, the regularization R-square was 0.882 . The significant institutional-social-ecological factors accounted for $88.2 \%$ of the residents' collective action performance. The regression results in Table 10 show that six institutional-social-ecological factors have a significant impact on residents' collective action performances, and their effect (coefficients) are presented in Figure 8. 


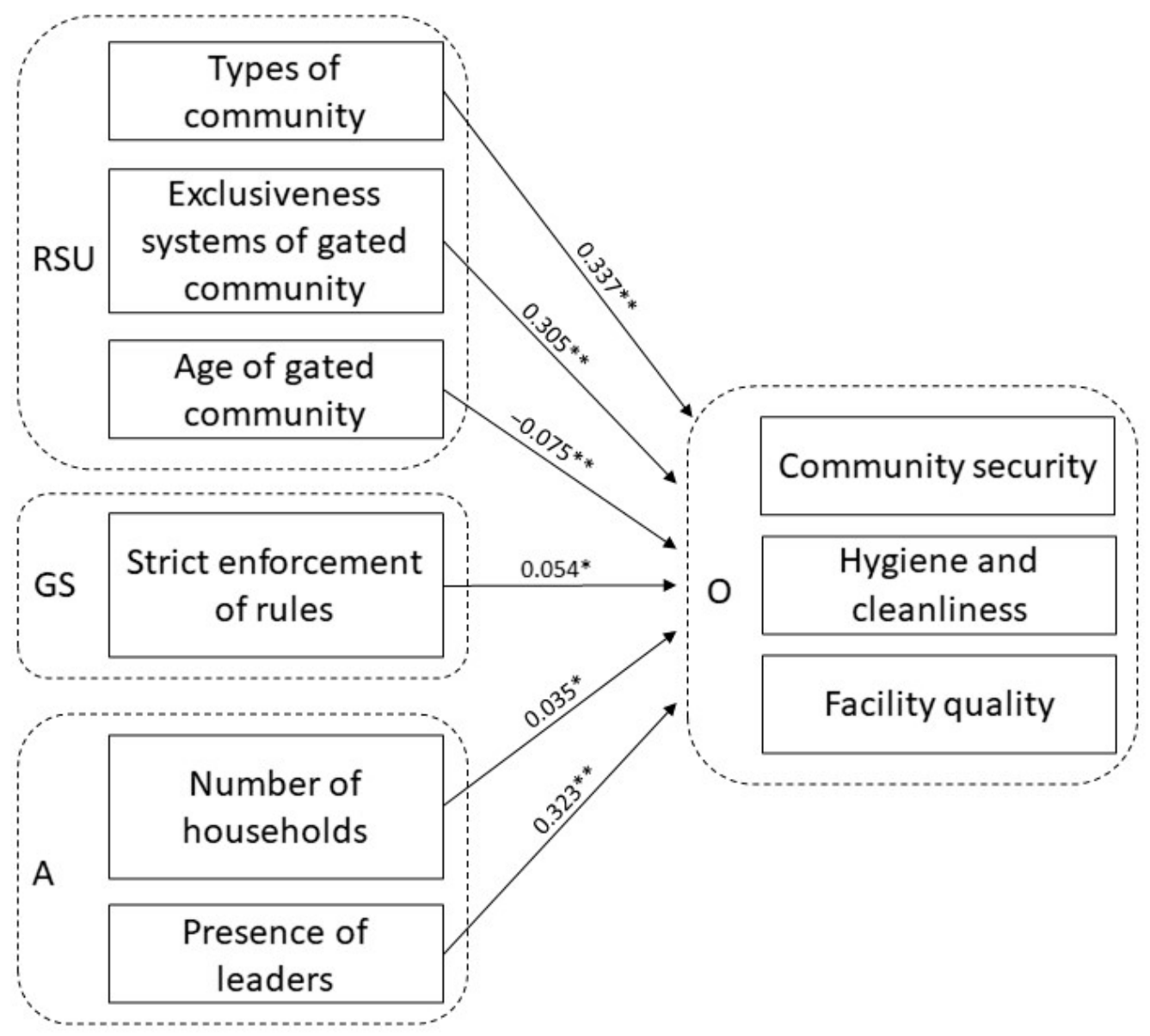

Figure 8. Institutional-social-ecological factor impact paths for residents' collective action performances, where ${ }^{*}$ is $p<5 \%$; ${ }^{* *}$ is $p<1 \%$.

In resource systems and units (RSU), the types of community posed an incredibly remarkable impact upon residents' collective action performances, in which post-workplace communities with affiliated workplaces had the best commons self-organizing management performance; this is because, since the time of "China's reform and opening-up", the most retained state-owned workplaces have increased the levels of economic benefits, and residents in gated communities have a more stable income. Furthermore, the retained state-owned workplaces have beneficial welfare systems, and some workplaces can provide assistance regarding service facilities' construction and management for subordinate communities. The commons management performance in new gated communities composed of commodity housing is also seen in a positive light, as most residents living in such gated communities are relatively rich. Relevant empirical studies indicated that richer residents have a stronger awareness of protecting their private property [56], and the material benefits of protecting housing property motivate owners to have a higher level of consciousness surrounding local affairs [72]. As such, residents actively participate more often and invest in commons management as well. As the welfare policy of the Chinese government, new communities have also built subsidized housing and low-rent housing. The commons management performance in this type of gated community was worse than that of new communities with only commodity housing. Considering the socioeconomic status of low-income residents, the purpose of these types of gated communities is not to provide an extreme living environment, and the low-income residents are unable to invest highly in commons management fees. Furthermore, for the residents in low-rent housing, their housing is provided by the social welfare system and does not belong to them as private property. Thus, their consciousness of property rights protections is lower $[51,66]$. The gated communities with the worst collective action performance were the post-workplace 
communities without affiliated workplaces. In this gated community, the affluent residents commonly move out to gated communities with a better environment, and as the original subordinate workplaces were closed down, the remaining residents could not achieve a steady income or the ability to invest an increased amount of capital into commons management. In addition to the former staff of a workplace, several less affluent foreigners have moved in. Consequently, this kind of gated community is more likely to become a slum in the city.

Based upon the above-mentioned analysis findings, the old post-workplace gated communities without affiliated workplaces are the most apparent areas of decline in urban settlements in China. Urban and community managers should pay special attention to preventing this type of community from developing into urban slums. In response to this problem, managers can improve community security and isolate adverse external factors by upgrading access control systems in a community. As the post-workplace communities themselves have a solid foundation of industrial predestined relationships with residents, which, moreover, can be utilized to develop democratic community systems, through the democratic election of residential leaders, they can organize collective action and improve residents' collective action performances. Foster [11] stated that gated communities are the mark of a "social governance revolution" of the urban commons and that the development of gated communities and owner associations can hasten this process rapidly. China's post-workplace communities have a solid foundation of social bonds that can be used to develop residents' democratic autonomy.

Through the comparison of residents' collective action performances in post-workplace communities without affiliated workplaces and new communities, it is proven that the Chinese government is effective in solving problems from social class differentiation. China's housing policy can prevent the decline of some urban areas due to the sizeable aggregation of low-income groups, and enable low-income groups to achieve average living conditions. Nonetheless, to achieve an improved living environment, the new communities still need to consider the optimization of commons management rules and the development of social democracy within communities, particularly communities that are composed of residents with various social classes to improve the residents' collective action performance.

The exclusive systems of gated communities had consequential positive effects upon residents' collective action performances; stricter access control of a gated community can improve the residents' sense of security [47] and Cai et al. [73] found that residents living in communities with higher levels of exclusivity have a stronger consciousness concerning property rights protections. As one of the fundamental characteristics of gated communities, access control has a significant positive effect on the isolation of external adverse impacts and upon the cultivation of residents' sense of property rights protections. The age of gated communities had a negative effect on collective action performance. A number of older gated communities may be in disrepair, the reason for this being that, with the greater age of the multi-owned residential buildings, its owner group will expect diminishing returns related to management investment, thus contributing to a weakening of the enthusiasm of the owners to participate in the collective management of the gated communities [45].

In governance systems, strict commons management rules had a positive effect on regulating residents' collective actions. Chen and Webster [42] believed that it is unrealistic to rely only on members' consciences, unity, full consensus, and altruism to maintain cooperation in self-organizing management; without the power to enforce rules, members' trust in an institution will inevitably be under pressure and weakened. Levi [74] illustrated this problem with the concept of "quasi-voluntary" which is when taxpayers will comply with the rules and pay tax voluntarily only when they perceive that the collective objective is achieved, and when they also perceive that others also comply. Coercion is a required condition for the realization of "quasi-voluntary" compliance, as enforcement enhances the individual's confidence and makes them hold a belief that they will not be deceived. When "other people" leave the team, the feedback effect will make the individual's trust 
in the system collapse quickly. Strict commons management and enforcement rules can help prevent the free-riding behavior of residents; additionally, they build a sense of trust among residents, which improves residents' collective action performance.

For actors' attributes, the larger size of gated communities had a weak positive impact upon the collective action and commons management in gated communities, and the finding is contrary to Olson's collective action theory in which small groups perform better than larger groups [27]. Gao and Ho [45] obtained a similar finding to Olson's in the study of property owners' cooperative ability in multi-owned residential buildings in Hong Kong. This may be due to the development trend in China's gated communities. With the increase in the urban population and the improvement of construction technology in China, newer gated communities commonly have a larger household capacity; or, because large-size gated communities are more difficult to manage to make up for this defect, commons management participants in gated communities tend to invest an increased amount of capital and energy. Moreover, another possibility is that a larger community may have additional resources (e.g., financial aid) that are especially helpful in relieving the insufficient management funding issue (see Oliver and Marwell [75]). Nevertheless, the group size effect certainly needs to be verified in further research. The presence of leaders played a remarkable positive role in the residents' collective action performance, where Cai and Sheng [57] believed that leaders in gated communities have the following roles. First, they can be the first to uncover the encroachment of interests by developers, management companies, or government agencies, and raise awareness among their fellow homeowners. Second, they serve as initiators and organizers who inspire and mobilize homeowners in the participation of rights-defending activities or homeowners' organizing. Third, they make strategic decisions and devise strategies to fight more effectively against the adversaries of homeowners. Beneficial strategies directly contribute to success. Fourth, they represent other homeowners when negotiating with the opposing parties. Residential leaders can help gated communities in the establishment of multi-level management systems by multilevel residential leaders, such as community leaders, zoning leaders and building leaders; this is a low-cost path forward when realizing multi-level management systems in large gated communities.

\section{Conclusions}

This study, among 14 SES factors, has identified six institutional-social-ecological factors based on the ridge regression model, which provides an integrated view on what are those key factors and how are they are associated with the collective action of gated communities in terms of community security, hygiene and cleanliness, and facility quality. According to the standardized effect size in descending order, those factors are: (i) types of community; (ii) presence of leaders; (iii) exclusiveness systems of gated communities; (iv) age of gated community; (v) strict enforcement of rules; and (vi) number of households. In other words, types of community, the presence of leaders, and exclusiveness systems are the three most important factors influencing the collective actions of gated communities. Consequently, by confirming conclusions of previous studies on what yields better collective action, the study supported the following hypotheses: $\mathrm{H1}$, that post workplace communities with affiliated workplaces are likely to have more effective collective action; $\mathrm{H} 2$, that stricter access control has a positive effect on collective action; $\mathrm{H} 3$, that the older the community, the lower the collective action effectiveness; $\mathrm{H7}$, that stricter enforcement of collective rules is better for collective action; and H12, that the presence of leaders yields better collective action in gated communities. Not only does the study offer global and national policy implications in terms of realizing sustainable development in urban settlements, vitally contributing to Sustainable Development Goal 11 (SDG 11); more precisely, the sustainable development target (SDT) 111 particularly for pushing cities and human settlements to be inclusive, safe, resilient, and sustainable as well as Article 46 of the New Urban Agenda and China's 14th Five-Year Plan (2021-2025) on improving urban quality (see Part VIII, Chapter 29), it also has practical significance where the findings on the key 
identified SES factors render valuable insights to Chinese urban and community managers in formulating effective and strategic housing and building governance and management measures so as to improve collective action in gated communities.

Despite the above contributions, this study, nevertheless, has limitations. First, since this study's findings are based on only one province, further empirical validation of the identified SES factors in other geographical and housing contexts is necessary. Furthermore, exploration of other second-level social-ecological attributes (confounding factors) and mediating components via a multi-stakeholder research design to demonstrate more accurate processes and mechanisms on how the relationships work is worthy of future study.

Author Contributions: Conceptualization, X.S. and G.H.T.L.; methodology, X.S. and G.H.T.L.; software, X.S.; validation, G.H.T.L.; formal analysis, X.S. and G.H.T.L.; investigation, X.S.; resources, X.S.; data curation, X.S.; writing — original draft preparation, X.S. and G.H.T.L.; writing-review and editing, X.S. and G.H.T.L.; visualization, X.S. and G.H.T.L.; supervision, G.H.T.L.; project administration, G.H.T.L. All authors have read and agreed to the published version of the manuscript.

Funding: This research received no external funding.

Institutional Review Board Statement: Not applicable.

Informed Consent Statement: Not applicable.

Data Availability Statement: The data presented in this study are available in this article.

Conflicts of Interest: The authors declare no conflict of interest.

\section{Appendix A}

Questionnaire:

Do you think the community you live in is safe?

A. Unsafe

B. Medium

C. Safe

What do you think of the hygiene status of the community you live in?

A. Dirty

B. Medium

C. Clean

What do you think of the quality of public service facilities in the community you live in?

A. Poor

B. Medium

C. Clean

What kind of community you living in?

A. Post workplace community (affiliated workplace exists)

B. Post workplace community (affiliated workplace does not exist)

C. New community (commodity residential community)

D. New community (mixed community with commodity housing and subsidized housing)

E. New community (mixed community with commodity housing, subsidized housing and low-rent housing)

What kind of access control system in the community you living in?

A. Neighbors that have no walls/gates

B. Free access neighbors with walls and gates, but no access control

C. Strictly restrict the entry of outsiders

How many years has your community been built? Years

Do you think the public service facilities in your community (such as garbage cans, parking spaces, green spaces, etc.) are sufficient?
A. Very shortage
B. Shortage
C. Passable
D. Enough
E. Ample 
What are the participants involved in commons' self-organization management in the gated community you living in?
A. All residents participate in commons' management

B. Only property owners participate in commons' self-organization management of gated community

Have some residents violated rules but they did not be punished in the community you living in?

A. Yes

B. No

Have the clear the commons' management rules or covenants in the community you living in?

A. Yes

B. No

Households

How much money is your housing price now? Yuan $/ \mathrm{m}^{2}$

Did your community ever elect leaders or president of building?

A. No

B. Yes

Do you willing to continually live in your gated community in the future?

A. Want to move out

B. Doing not intend to live long

C. Uncertain

D. No plans to move out

E. Wish to live permanently in this community

Whether you are satisfied for the environment of your gated community?
A. Very dissatisfied
B. Dissatisfied
C. So-so
D. Satisfied
E. Very satisfied

Table A1. Ridge models.

\begin{tabular}{|c|c|c|c|c|c|c|c|c|c|}
\hline \multicolumn{7}{|c|}{ Ridge Models } & & & \\
\hline & & & & Apparent & $\begin{array}{r}\text { Expe } \\
\text { S }\end{array}$ & $\begin{array}{l}\text { ed Predictio } \\
\text { ndardized D }\end{array}$ & & $\begin{array}{r}\text { Expected } \\
\text { Error } R\end{array}$ & $\begin{array}{l}\text { rediction } \\
\text { w Data }\end{array}$ \\
\hline & & & & & Estimate $^{a}$ & Std. Error & $\mathbf{N}^{\mathbf{b}}$ & Estimate $^{a}$ & Std. Error \\
\hline 1 & 0 & 0.891 & 1 & 0.109 & 0.13 & 0.013 & 414 & 0.289 & 0.03 \\
\hline $2^{c}$ & 0.01 & 0.892 & 0.09 & 0.108 & 0.123 & 0.013 & 414 & 0.274 & 0.028 \\
\hline 3 & 0.02 & 0.892 & 0.064 & 0.108 & 0.123 & 0.013 & 414 & 0.274 & 0.028 \\
\hline 4 & 0.03 & 0.891 & 0.058 & 0.109 & 0.124 & 0.013 & 414 & 0.276 & 0.029 \\
\hline 5 & 0.04 & 0.889 & 0.053 & 0.111 & 0.124 & 0.013 & 414 & 0.275 & 0.029 \\
\hline 6 & 0.05 & 0.888 & 0.05 & 0.112 & 0.125 & 0.013 & 414 & 0.277 & 0.029 \\
\hline 7 & 0.06 & 0.886 & 0.047 & 0.114 & 0.128 & 0.014 & 414 & 0.284 & 0.03 \\
\hline 8 & 0.07 & 0.885 & 0.045 & 0.115 & 0.129 & 0.014 & 414 & 0.287 & 0.03 \\
\hline 9 & 0.08 & 0.884 & 0.042 & 0.116 & 0.131 & 0.014 & 414 & 0.29 & 0.03 \\
\hline 10 & 0.09 & 0.883 & 0.041 & 0.117 & 0.132 & 0.014 & 414 & 0.293 & 0.03 \\
\hline $11^{\mathrm{d}}$ & 0.1 & 0.882 & 0.039 & 0.118 & 0.133 & 0.014 & 414 & 0.296 & 0.031 \\
\hline 12 & 0.11 & 0.879 & 0.036 & 0.121 & 0.138 & 0.015 & 414 & 0.306 & 0.032 \\
\hline 13 & 0.12 & 0.878 & 0.034 & 0.122 & 0.139 & 0.015 & 414 & 0.308 & 0.032 \\
\hline 14 & 0.13 & 0.876 & 0.033 & 0.124 & 0.14 & 0.015 & 414 & 0.312 & 0.033 \\
\hline 15 & 0.14 & 0.875 & 0.032 & 0.125 & 0.142 & 0.015 & 414 & 0.315 & 0.033 \\
\hline
\end{tabular}


Table A1. Cont.

\begin{tabular}{|c|c|c|c|c|c|c|c|c|c|}
\hline \multicolumn{10}{|c|}{ Ridge Models } \\
\hline & \multirow{2}{*}{ Penalty } & \multirow{2}{*}{$\begin{array}{l}\text { Regularization “R } \\
\text { Square" (1-Error) }\end{array}$} & \multirow{2}{*}{$\begin{array}{c}\text { Standardized Sum } \\
\text { of Coefficients }\end{array}$} & \multirow{2}{*}{$\begin{array}{c}\text { Apparent } \\
\text { Prediction Error }\end{array}$} & \multicolumn{3}{|c|}{$\begin{array}{l}\text { Expected Prediction Error } \\
\text { Standardized Data }\end{array}$} & \multicolumn{2}{|c|}{$\begin{array}{l}\text { Expected Prediction } \\
\text { Error Raw Data }\end{array}$} \\
\hline & & & & & Estimate $^{\mathrm{a}}$ & Std. Error & $\mathrm{N}^{\mathrm{b}}$ & Estimate ${ }^{a}$ & Std. Error \\
\hline 16 & 0.15 & 0.874 & 0.031 & 0.126 & 0.142 & 0.015 & 414 & 0.315 & 0.032 \\
\hline 17 & 0.16 & 0.872 & 0.03 & 0.128 & 0.143 & 0.015 & 414 & 0.317 & 0.032 \\
\hline 18 & 0.17 & 0.871 & 0.029 & 0.129 & 0.145 & 0.015 & 414 & 0.321 & 0.033 \\
\hline 19 & 0.18 & 0.873 & 0.031 & 0.127 & 0.146 & 0.015 & 414 & 0.324 & 0.033 \\
\hline 20 & 0.19 & 0.868 & 0.027 & 0.132 & 0.148 & 0.015 & 414 & 0.328 & 0.033 \\
\hline 21 & 0.2 & 0.867 & 0.026 & 0.133 & 0.147 & 0.015 & 414 & 0.325 & 0.033 \\
\hline 22 & 0.21 & 0.866 & 0.026 & 0.134 & 0.149 & 0.015 & 414 & 0.331 & 0.034 \\
\hline 23 & 0.22 & 0.865 & 0.025 & 0.135 & 0.15 & 0.015 & 414 & 0.333 & 0.034 \\
\hline 24 & 0.23 & 0.864 & 0.025 & 0.136 & 0.151 & 0.015 & 414 & 0.335 & 0.034 \\
\hline 25 & 0.24 & 0.863 & 0.024 & 0.137 & 0.152 & 0.015 & 414 & 0.338 & 0.034 \\
\hline 26 & 0.25 & 0.862 & 0.024 & 0.138 & 0.153 & 0.016 & 414 & 0.34 & 0.034 \\
\hline 27 & 0.26 & 0.86 & 0.023 & 0.14 & 0.154 & 0.016 & 414 & 0.342 & 0.034 \\
\hline 28 & 0.27 & 0.86 & 0.023 & 0.14 & 0.155 & 0.016 & 414 & 0.343 & 0.034 \\
\hline 29 & 0.28 & 0.859 & 0.022 & 0.141 & 0.155 & 0.016 & 414 & 0.345 & 0.035 \\
\hline 30 & 0.29 & 0.857 & 0.022 & 0.143 & 0.157 & 0.016 & 414 & 0.348 & 0.035 \\
\hline 31 & 0.3 & 0.857 & 0.022 & 0.143 & 0.157 & 0.016 & 414 & 0.349 & 0.035 \\
\hline 32 & 0.31 & 0.856 & 0.021 & 0.144 & 0.158 & 0.016 & 414 & 0.351 & 0.035 \\
\hline 33 & 0.32 & 0.855 & 0.021 & 0.145 & 0.159 & 0.016 & 414 & 0.353 & 0.035 \\
\hline 34 & 0.33 & 0.854 & 0.02 & 0.146 & 0.159 & 0.016 & 414 & 0.354 & 0.035 \\
\hline 35 & 0.34 & 0.853 & 0.02 & 0.147 & 0.16 & 0.016 & 414 & 0.356 & 0.035 \\
\hline 36 & 0.35 & 0.852 & 0.02 & 0.148 & 0.161 & 0.016 & 414 & 0.357 & 0.035 \\
\hline 37 & 0.36 & 0.852 & 0.02 & 0.148 & 0.162 & 0.016 & 414 & 0.359 & 0.036 \\
\hline 38 & 0.37 & 0.851 & 0.019 & 0.149 & 0.163 & 0.016 & 414 & 0.362 & 0.036 \\
\hline 39 & 0.38 & 0.85 & 0.019 & 0.15 & 0.163 & 0.016 & 414 & 0.362 & 0.036 \\
\hline 40 & 0.39 & 0.849 & 0.019 & 0.151 & 0.164 & 0.016 & 414 & 0.364 & 0.036 \\
\hline 41 & 0.4 & 0.848 & 0.019 & 0.152 & 0.165 & 0.016 & 414 & 0.365 & 0.036 \\
\hline 42 & 0.41 & 0.847 & 0.018 & 0.153 & 0.165 & 0.016 & 414 & 0.367 & 0.036 \\
\hline 43 & 0.42 & 0.847 & 0.018 & 0.153 & 0.166 & 0.016 & 414 & 0.368 & 0.036 \\
\hline 44 & 0.43 & 0.846 & 0.018 & 0.154 & 0.167 & 0.016 & 414 & 0.37 & 0.036 \\
\hline 45 & 0.44 & 0.845 & 0.018 & 0.155 & 0.167 & 0.016 & 414 & 0.371 & 0.036 \\
\hline 46 & 0.45 & 0.844 & 0.017 & 0.156 & 0.168 & 0.017 & 414 & 0.373 & 0.037 \\
\hline 47 & 0.46 & 0.844 & 0.017 & 0.156 & 0.169 & 0.017 & 414 & 0.375 & 0.037 \\
\hline 48 & 0.47 & 0.843 & 0.017 & 0.157 & 0.169 & 0.017 & 414 & 0.376 & 0.037 \\
\hline 49 & 0.48 & 0.842 & 0.017 & 0.158 & 0.17 & 0.017 & 414 & 0.377 & 0.037 \\
\hline 50 & 0.49 & 0.842 & 0.017 & 0.158 & 0.17 & 0.017 & 414 & 0.378 & 0.037 \\
\hline 51 & 0.5 & 0.841 & 0.017 & 0.159 & 0.171 & 0.017 & 414 & 0.38 & 0.037 \\
\hline 52 & 0.51 & 0.84 & 0.016 & 0.16 & 0.172 & 0.017 & 414 & 0.381 & 0.037 \\
\hline 53 & 0.52 & 0.84 & 0.016 & 0.16 & 0.172 & 0.017 & 414 & 0.382 & 0.037 \\
\hline 54 & 0.53 & 0.839 & 0.016 & 0.161 & 0.173 & 0.017 & 414 & 0.384 & 0.037 \\
\hline 55 & 0.54 & 0.838 & 0.016 & 0.162 & 0.174 & 0.017 & 414 & 0.386 & 0.038 \\
\hline
\end{tabular}


Table A1. Cont.

\begin{tabular}{|c|c|c|c|c|c|c|c|c|c|}
\hline \multicolumn{10}{|c|}{ Ridge Models } \\
\hline & \multirow{2}{*}{ Penalty } & \multirow{2}{*}{$\begin{array}{l}\text { Regularization “R } \\
\text { Square" (1-Error) }\end{array}$} & \multirow{2}{*}{$\begin{array}{c}\text { Standardized Sum } \\
\text { of Coefficients }\end{array}$} & \multirow{2}{*}{$\begin{array}{c}\text { Apparent } \\
\text { Prediction Error }\end{array}$} & \multicolumn{3}{|c|}{$\begin{array}{l}\text { Expected Prediction Error } \\
\text { Standardized Data }\end{array}$} & \multicolumn{2}{|c|}{$\begin{array}{l}\text { Expected Prediction } \\
\text { Error Raw Data }\end{array}$} \\
\hline & & & & & Estimate $^{\mathrm{a}}$ & Std. Error & $\mathbf{N}^{\mathrm{b}}$ & Estimate ${ }^{a}$ & Std. Error \\
\hline 56 & 0.55 & 0.838 & 0.016 & 0.162 & 0.174 & 0.017 & 414 & 0.386 & 0.037 \\
\hline 57 & 0.56 & 0.837 & 0.016 & 0.163 & 0.175 & 0.017 & 414 & 0.388 & 0.038 \\
\hline 58 & 0.57 & 0.836 & 0.016 & 0.164 & 0.175 & 0.017 & 414 & 0.389 & 0.038 \\
\hline 59 & 0.58 & 0.836 & 0.015 & 0.164 & 0.176 & 0.017 & 414 & 0.39 & 0.038 \\
\hline 60 & 0.59 & 0.834 & 0.015 & 0.166 & 0.177 & 0.017 & 414 & 0.392 & 0.038 \\
\hline 61 & 0.6 & 0.834 & 0.015 & 0.166 & 0.177 & 0.017 & 414 & 0.393 & 0.038 \\
\hline 62 & 0.61 & 0.834 & 0.015 & 0.166 & 0.177 & 0.017 & 414 & 0.394 & 0.038 \\
\hline 63 & 0.62 & 0.833 & 0.015 & 0.167 & 0.178 & 0.017 & 414 & 0.395 & 0.038 \\
\hline 64 & 0.63 & 0.833 & 0.015 & 0.167 & 0.177 & 0.017 & 414 & 0.394 & 0.038 \\
\hline 65 & 0.64 & 0.832 & 0.015 & 0.168 & 0.179 & 0.017 & 414 & 0.397 & 0.038 \\
\hline 66 & 0.65 & 0.83 & 0.014 & 0.17 & 0.18 & 0.017 & 414 & 0.399 & 0.038 \\
\hline 67 & 0.66 & 0.831 & 0.014 & 0.169 & 0.18 & 0.017 & 414 & 0.4 & 0.039 \\
\hline 68 & 0.67 & 0.83 & 0.014 & 0.17 & 0.18 & 0.017 & 414 & 0.401 & 0.039 \\
\hline 69 & 0.68 & 0.83 & 0.014 & 0.17 & 0.181 & 0.018 & 414 & 0.402 & 0.039 \\
\hline 70 & 0.69 & 0.829 & 0.014 & 0.171 & 0.182 & 0.018 & 414 & 0.403 & 0.039 \\
\hline 71 & 0.7 & 0.829 & 0.014 & 0.171 & 0.182 & 0.018 & 414 & 0.404 & 0.039 \\
\hline 72 & 0.71 & 0.828 & 0.014 & 0.172 & 0.183 & 0.018 & 414 & 0.405 & 0.039 \\
\hline 73 & 0.72 & 0.828 & 0.014 & 0.172 & 0.183 & 0.018 & 414 & 0.406 & 0.039 \\
\hline 74 & 0.73 & 0.827 & 0.014 & 0.173 & 0.184 & 0.018 & 414 & 0.408 & 0.039 \\
\hline 75 & 0.74 & 0.826 & 0.014 & 0.174 & 0.184 & 0.018 & 414 & 0.409 & 0.039 \\
\hline 76 & 0.75 & 0.826 & 0.014 & 0.174 & 0.185 & 0.018 & 414 & 0.41 & 0.039 \\
\hline 77 & 0.76 & 0.833 & 0.015 & 0.167 & 0.185 & 0.018 & 414 & 0.411 & 0.039 \\
\hline 78 & 0.77 & 0.825 & 0.013 & 0.175 & 0.185 & 0.018 & 414 & 0.412 & 0.039 \\
\hline 79 & 0.78 & 0.825 & 0.013 & 0.175 & 0.186 & 0.018 & 414 & 0.413 & 0.039 \\
\hline 80 & 0.79 & 0.824 & 0.013 & 0.176 & 0.186 & 0.018 & 414 & 0.414 & 0.04 \\
\hline 81 & 0.8 & 0.823 & 0.013 & 0.177 & 0.187 & 0.018 & 414 & 0.415 & 0.04 \\
\hline 82 & 0.81 & 0.822 & 0.013 & 0.178 & 0.188 & 0.018 & 414 & 0.416 & 0.04 \\
\hline 83 & 0.82 & 0.822 & 0.013 & 0.178 & 0.188 & 0.018 & 414 & 0.417 & 0.04 \\
\hline 84 & 0.83 & 0.822 & 0.013 & 0.178 & 0.188 & 0.018 & 414 & 0.418 & 0.04 \\
\hline 85 & 0.84 & 0.821 & 0.013 & 0.179 & 0.189 & 0.018 & 414 & 0.419 & 0.04 \\
\hline 86 & 0.85 & 0.821 & 0.013 & 0.179 & 0.189 & 0.018 & 414 & 0.42 & 0.04 \\
\hline 87 & 0.86 & 0.82 & 0.013 & 0.18 & 0.19 & 0.018 & 414 & 0.421 & 0.04 \\
\hline 88 & 0.87 & 0.82 & 0.013 & 0.18 & 0.19 & 0.018 & 414 & 0.422 & 0.04 \\
\hline 89 & 0.88 & 0.819 & 0.013 & 0.181 & 0.191 & 0.018 & 414 & 0.423 & 0.04 \\
\hline 90 & 0.89 & 0.819 & 0.013 & 0.181 & 0.191 & 0.018 & 414 & 0.423 & 0.04 \\
\hline 91 & 0.9 & 0.818 & 0.013 & 0.182 & 0.191 & 0.018 & 414 & 0.424 & 0.04 \\
\hline 92 & 0.91 & 0.818 & 0.013 & 0.182 & 0.192 & 0.018 & 414 & 0.426 & 0.04 \\
\hline 93 & 0.92 & 0.816 & 0.012 & 0.184 & 0.192 & 0.018 & 414 & 0.427 & 0.04 \\
\hline 94 & 0.93 & 0.817 & 0.012 & 0.183 & 0.192 & 0.018 & 414 & 0.425 & 0.04 \\
\hline 95 & 0.94 & 0.817 & 0.012 & 0.183 & 0.193 & 0.018 & 414 & 0.428 & 0.041 \\
\hline
\end{tabular}


Table A1. Cont.

\begin{tabular}{|c|c|c|c|c|c|c|c|c|c|}
\hline \multicolumn{10}{|c|}{ Ridge Models } \\
\hline & \multirow{2}{*}{ Penalty } & \multirow{2}{*}{$\begin{array}{l}\text { Regularization “R } \\
\text { Square" (1-Error) }\end{array}$} & \multirow{2}{*}{$\begin{array}{l}\text { Standardized Sum } \\
\text { of Coefficients }\end{array}$} & \multirow{2}{*}{$\begin{array}{c}\text { Apparent } \\
\text { Prediction Error }\end{array}$} & \multicolumn{3}{|c|}{$\begin{array}{l}\text { Expected Prediction Error } \\
\text { Standardized Data }\end{array}$} & \multicolumn{2}{|c|}{$\begin{array}{l}\text { Expected Prediction } \\
\text { Error Raw Data }\end{array}$} \\
\hline & & & & & Estimate ${ }^{a}$ & Std. Error & $\mathbf{N}^{\mathbf{b}}$ & Estimate $^{a}$ & Std. Error \\
\hline 96 & 0.95 & 0.816 & 0.012 & 0.184 & 0.193 & 0.018 & 414 & 0.429 & 0.041 \\
\hline 97 & 0.96 & 0.816 & 0.012 & 0.184 & 0.194 & 0.018 & 414 & 0.43 & 0.041 \\
\hline 98 & 0.97 & 0.815 & 0.012 & 0.185 & 0.194 & 0.018 & 414 & 0.431 & 0.041 \\
\hline 99 & 0.98 & 0.815 & 0.012 & 0.185 & 0.195 & 0.018 & 414 & 0.432 & 0.041 \\
\hline 100 & 0.99 & 0.814 & 0.012 & 0.186 & 0.195 & 0.019 & 414 & 0.433 & 0.041 \\
\hline 101 & 1 & 0.814 & 0.012 & 0.186 & 0.195 & 0.019 & 414 & 0.434 & 0.041 \\
\hline
\end{tabular}

${ }^{a}$ Mean Squared Error (10 fold Cross Validation). ${ }^{b}$ If $\mathrm{N}$ is smaller than the number of active (training) cases, this is due to excluding cases from estimation of the expected prediction error for reason(s) explained in the warning table. ${ }^{\mathrm{c}}$ Optimal model: $2 .{ }^{\mathrm{d}}$ Selected model/Parsimonious model: 11.

\section{References}

1. Bangura, M.; Lee, C.L. The Determinants of Homeownership Affordability in Greater Sydney: Evidence from a Submarket Analysis. Housing Studies. Available online: https:/ / www.tandfonline.com/doi/abs/10.1080/02673037.2021.1879995 (accessed on 1 February 2022).

2. Rañeses, M.K.; Chang-Richards, A.; Wang, K.I.K.; Dirks, K.N. Housing for Now and the Future: A Systematic Review of Climate-Adaptive Measures. Sustainability 2021, 13, 6744. [CrossRef]

3. Wang, J.; Lee, C.L. The value of air quality in housing markets: A comparative study of housing sale and rental markets in China. Energy Policy 2022, 160, 112601. [CrossRef]

4. Kuang, W.; Li, X. Does China face a housing affordability issue? Evidence from 35 cities in China. Int. J. Hous. Mark. Anal. 2012, 5 , 272-288. [CrossRef]

5. Shi, W.; Chen, J.; Wang, H. Affordable housing policy in China: New developments and new challenges. Habitat Int. 2016, 54, 224-233. [CrossRef]

6. Webster, C.; Wu, F.; Zhang, F.; Sarkar, C. Informality, property rights, and poverty in China's "favelas". World Dev. 2016, 78, 461-476. [CrossRef]

7. Xue, J. Sustainable housing development: Decoupling or degrowth? A comparative study of Copenhagen and Hangzhou. Environ. Plan. C Gov. Policy 2015, 33, 620-639. [CrossRef]

8. Yu, T.; Shen, G.Q.; Shi, Q.; Zheng, H.W.; Wang, G.; Xu, K. Evaluating social sustainability of urban housing demolition in Shanghai, China. J. Clean. Prod. 2017, 153, 26-40. [CrossRef]

9. Li, L.; Wan, W.X.; He, S. The Heightened 'Security Zone' Function of Gated Communities during the COVID-19 Pandemic and the Changing Housing Market Dynamic: Evidence from Beijing, China. Land 2021, 10, 983. [CrossRef]

10. Hardin, G. The tragedy of the commons: The population problem has no technical solution; it requires a fundamental extension in morality. Science 1968, 162, 1243-1248. [CrossRef]

11. Foster, S.R. Collective action and the urban commons. Notre Dame Law Rev. 2011, 87, 57.

12. Douglass, M.; Wissink, B.; Van Kempen, R. Enclave urbanism in China: Consequences and interpretations. Urban Geogr. 2012, 33, 167-182. [CrossRef]

13. Wu, F. China's great transformation: Neoliberalization as establishing a market society. Geoforum 2008, 39, 1093-1096. [CrossRef]

14. He, S.; Wang, K. Enclave urbanism. In The Wiley Blackwell Encyclopedia of Urban and Regional Studies; Orum, A.M., Ed.; John Wiley \& Sons: New York, NY, USA, 2019.

15. Atkinson, R.; Blandy, S. Introduction: International perspectives on the new enclavism and the rise of gated communities. Hous. Stud. 2005, 20, 177-186. [CrossRef]

16. Glasze, G.; Webster, C.; Frantz, K. Private Cities: Global and Local Perspectives, 1st ed.; Routledge: London, UK, 2004.

17. Webster, C.; Glasze, G.; Frantz, K. The global spread of gated communities. Environ. Plan. B Plan. Des. 2002, 29, 315-320. [CrossRef]

18. Blakely, E.J.; Snyder, M.G. Fortress America: Gated communities in the United States; Brookings Institution Press: Washington, DC, USA, 1997.

19. Caldeira, T.P.R. Fortified enclaves: The new urban segregation. In The Urban Sociology Reader; Lin, J., Mele, C., Eds.; Routledge: London, UK, 2012; pp. 419-427.

20. Low, S. Behind the Gates: Life, Security, and the Pursuit of Happiness in Fortress America; Routledge: London, UK, 2004.

21. Ostrom, E. Governing the Commons: The Evolution of Institutions for Collective Action; Cambridge University Press: Cambridge, UK, 1990.

22. Ostrom, E. Understanding Institutional Diversity; Princeton University Press: Princeton, NJ, USA, 2005. 
23. Wang, H.K.; Ling, G.H.T.; Shi, X. Collective Action Components of Low-Cost Housing: An Empirical Analysis Using Ostrom's SES Framework. Property Management. Available online: https://www.emerald.com/insight/content/doi/10.1108/PM-07-202 1-0053/full/html (accessed on 1 February 2022).

24. Sun, G.; Webster, C. The security grills on apartments in gated communities: Trading-off 3D and 2D landscapes of fear in China. Cities 2019, 90, 113-121. [CrossRef]

25. Wang, Z.; Liu, L.; Haberman, C.; Lan, M.; Yang, B.; Zhou, H. Burglaries and entry controls in gated communities. Urban Stud. 2021, 58, 2920-2932. [CrossRef]

26. He, S.; Wang, K. Homeowner Association in Guangzhou's Gated Communities: Devleopment Characteristics, Governance Efficacy and Its Determinants. Trop. Geogr. 2015, 35, 471-480.

27. Olson, M. The Logic of Collective Action: Public Goods and the Theory of Groups; Harvard University Press: Cambridge, MA, USA, 1965.

28. Webster, C. Property rights, public space and urban design. Town Plan. Rev. 2007, 78, 81-101. [CrossRef]

29. Kiser, L.; Ostrom, E. Strategies of Political Inquiry; SAGE Publications: Beverly Hills, CA, USA, 1982; pp. $179-222$.

30. Ostrom, E. A general framework for analyzing sustainability of social-ecological systems. Science 2009, 325, 419-422. [CrossRef]

31. Cole, D.; Epstein, G.; McGinnis, M. The utility of combining the IAD and SES frameworks. Int. J. Commons 2019, 13, 244-275. [CrossRef]

32. Wang, Y.; Zang, L.; Araral, E. The impacts of land fragmentation on irrigation collective action: Empirical test of the socialecological system framework in China. J. Rural Stud. 2020, 78, 234-244. [CrossRef]

33. Su, Y.; Araral, E.; Wang, Y. The effects of farmland use rights trading and labor outmigration on the governance of the irrigation commons: Evidence from China. Land Use Policy 2020, 91, 104378. [CrossRef]

34. Xie, Y.; Wen, Y.; Cirella, G.T. Application of Ostrom's social-ecological systems framework in nature reserves: Hybrid psychoeconomic model of collective forest management. Sustainability 2019, 11, 6929. [CrossRef]

35. Anderies, J.M.; Janssen, M.A. Robustness of social-ecological systems: Implications for public policy. Policy Stud. J. 2013, 41, 513-536. [CrossRef]

36. Nagendra, H.; Ostrom, E. Applying the social-ecological system framework to the diagnosis of urban lake commons in Bangalore, India. Ecol. Soc. 2014, 19, 67. [CrossRef]

37. Ling, G.H.T.; Leng, P.C.; Ho, C.S. Effects of diverse property rights on rural neighbourhood public open space (POS) governance: Evidence from Sabah, Malaysia. Economies 2019, 7, 61. [CrossRef]

38. Ling, G.H.T.; Leng, P.C.; Rusli, N.; Shin, W. A DSR Methodology for Conceptual Solution Development of Public Open Space Governance. J. Reg. City Plan. 2021, 32, 15-35. [CrossRef]

39. Ling, G.H.T.; Suhud, M.; Leng, P.C.; Yeo, L.B.; Cheng, C.T.; Ahmad, M.H.H.; Ak Matusin, A.M.R. Factors Influencing Asia-Pacific Countries' Success Level in Curbing COVID-19: A Review Using a Social-Ecological System (SES) Framework. Int. J. Environ. Res. Public Health 2021, 18, 1704. [CrossRef]

40. Zhao, P.; Zhang, M. Informal suburbanization in Beijing: An investigation of informal gated communities on the urban fringe. Habitat Int. 2018, 77, 130-142. [CrossRef]

41. Donoso, R.E.; Elsinga, M. Management of low-income condominiums in Bogotá and Quito: The balance between property law and self-organisation. Int. J. Hous. Policy 2018, 18, 312-334. [CrossRef]

42. Chen, S.C.; Webster, C.J. Homeowners associations, collective action and the costs of private governance. Hous. Stud. 2005, 20, 205-220. [CrossRef]

43. Zou, Y.; Zhao, W. Neighbourhood Governance during the COVID-19 Lockdown in Hangzhou: Coproduction Based on Digital Technologies. Public Management. Available online: https:/ /www.tandfonline.com/doi/abs/10.1080/14719037.2021.1945666 (accessed on 19 October 2021).

44. Yau, Y. Homeowners' participation in management of multi-storey residential buildings: The Hong Kong's case. Prop. Manag. 2011, 29, 345-356. [CrossRef]

45. Gao, L.W.; Ho, D.C. Explaining the outcomes of multi-owned housing management: A collective action perspective. Habitat Int. 2016, 57, 233-241. [CrossRef]

46. McGinnis, M.D.; Ostrom, E. Social-ecological system framework: Initial changes and continuing challenges. Ecol. Soc. 2014, 19, 30. [CrossRef]

47. Yip, N.M. Walled without gates: Gated communities in Shanghai. Urban Geogr. 2012, 33, 221-236. [CrossRef]

48. Shamsuddin, S.; Zaini, K. The Influence of the Surveillance Factors towards the Residents' Perceptions on Safety at the Shared Outdoor Spaces in Gated Community. Adv. Mater. Res. 2013, 838-841, 2942-2947. [CrossRef]

49. Muiga, J.G.; Rukwaro, R.W. Satisfaction of residents with gated community lifestyle: The case of Nairobi County; Kenya. Int. J. Humanit. Arts Med. Sci. (BEST IJHAMS) 2016, 4, 85-104.

50. Littlewood, A.; Munro, M. Explaining disrepair: Examining owner occupiers' repair and maintenance behaviour. Hous. Stud. 1996, 11, 503-525. [CrossRef]

51. Chen, C.Y.; Webster, C. Privatising the governance and management of existing urban neighbourhoods. Prop. Manag. 2006, 24, 98-115. [CrossRef]

52. Loo, F.K. A Guide to Effective Property Management in Hong Kong; Hong Kong University Press: Hong Kong, China, 1994.

53. Li, L.H. Managing community in Hong Kong-the political economy perspective. Prop. Manag. 2005, 23, $122-136$. 
54. Orbán, A. Community Action for Collective Goods: An Interdisciplina[r]y Approach to the Internal and External Solutions to Collective Action Problems: The Case of Hungarian Condominiums; Akademiai Kiado: Budapest, Hungary, 2006.

55. Yau, Y. Perceived efficacies and collectivism in multi-owned housing management. Habitat Int. 2014, 43, 133-141. [CrossRef]

56. Osman, M.M.; Rabe, N.S.; Bachok, S. An investigation of factors influencing communities decision to reside in gated development in Kuala Lumpur and Selangor. In Proceedings of the 11th International Congress of Asian Planning Schools Association (APSA, 2011), Tokyo, Japan, 19-22 September 2011; pp. 1-12.

57. Cai, Y.; Sheng, Z. Homeowners' activism in Beijing: Leaders with mixed motivations. China Q. 2013, 215, 513-532. [CrossRef]

58. Roitman, S. Urban Social Group Segregation: A Gated Community in Mendoza, Argentina. Ph.D. Thesis, University of London, London, UK, 2007.

59. Chavis, D.M.; Wandersman, A. Sense of Community in the Urban Environment: A Catalyst for Participation and Community Development. Am. J. Community Psychol. 1990, 18, 55-81. [CrossRef]

60. Wandersman, A. A framework of participation in community organizations. J. Appl. Behav. Sci. 1981, 17, 27-58. [CrossRef]

61. Landman, K.; Schönteich, M. Urban fortresses: Gated communities as a reaction to crime. Afr. Secur. Rev. 2002, 11, 71-85. [CrossRef]

62. Geniş, Ş. Producing elite localities: The rise of gated communities in Istanbul. Urban Stud. 2007, 44, 771-798. [CrossRef]

63. Mahgoub, Y.; Khalfani, F. Sustainability of gated communities in developing countries. Dev. Country Stud. 2012, 2, 53-63.

64. Blandy, S.; Lister, D. Gated communities:(ne) gating community development? Hous. Stud. 2005, 20, 287-301. [CrossRef]

65. Xie, Y.; Xie, S. Contentious versus Compliant: Diversified Patterns of Shanghai Homeowners' Collective Mobilizations. J. Contemp. China 2019, 28, 81-98. [CrossRef]

66. Tomba, L. Residential space and collective interest formation in Beijing's housing disputes. China Q. 2005, 184, 934-951. [CrossRef]

67. Pavlov, A.; Blazenko, G. The neighborhood effect of real estate maintenance. J. Real Estate Financ. Econ. 2005, 30, 327-340. [CrossRef]

68. Ye, Y. 70 years of housing development in China. Urban Rural. Dev. 2019, 2019, 6-9. (In Chinese)

69. Fan, Z.; Jiang, Z. From workplace communities to post-workplace communities: The logic of collective action in community from the perspective of organizational field. Decis.-Mak. Consult. 2020, 2020, 90-96.

70. Krejcie, R.V.; Morgan, D.W. Determining sample size for research activities. Educ. Psychol. Meas. 1970, 30, 607-610. [CrossRef]

71. Hoerl, A.E.; Kennard, R.W. Ridge regression: Biased estimation for nonorthogonal problems. Technometrics 1970, 12 , 55-67. [CrossRef]

72. Cox, K.R. Housing tenure and neighborhood activism. Urban Aff. Q. 1982, 18, 107-129. [CrossRef]

73. Cai, R.; Li, C.; He, S. Consciousness on property rights, homeowner associations and neighbourhood governance: Evidence from Shanghai. Cities 2021, 119, 103350. [CrossRef]

74. Levi, M. Of Rule and Revenue; University of California Press: Berkeley, CA, USA, 1989.

75. Oliver, P.E.; Marwell, G. The paradox of group size in collective action: A theory of the critical mass. II. Am. Sociol. Rev. 1988, 53, 1-8. [CrossRef] 